\title{
Driving Forces and Flow Mechanisms of the Atlantic Ocean Currents
}

\author{
Kari Hänninen \\ Department of Biological and Environmental Sciences, University of Jyväskylä, Finland \\ Received December 10, 2019; Revised January 27, 2020; Accepted February 7, 2020
}

Copyright $\odot 2020$ by authors, all rights reserved. Authors agree that this article remains permanently open access under the terms of the Creative Commons Attribution License 4.0 International License

\begin{abstract}
The aim of the study is to clarify the driving forces and flow mechanisms of ocean currents. The primary driving forces of the surface currents are the thrust by the trade winds and westerlies. For the undercurrents, the driving force is the thrust of descending salty water (DSW) formed in the Arctic and Southern Oceans by brine ejection from ice. The annual production of DSW in the Arctic Ocean is 21.7 Sv and in the Southern Ocean $26 \mathrm{~Sv}$. The annual average downward thrust created for the outflowing undercurrents in both oceans is $44,000 \mathrm{~N} / \mathrm{m}^{2}$. Most of the DSW outflow from the Arctic Ocean occurs via the Labrador Sea towards the coast of northwest Africa as the North Atlantic Undercurrent (NAUC). The direction of the flow is towards the suction at the starting point of the North Equatorial Current. The flow and the fluid dynamics of the NAUC follow Pascal's law and Bernoulli's equation. Upwelling provides an unobstructed passage for the continuous flow of an undercurrent. The water molecules moving along streamlines trade speed for height or for pressure. Due to this exchange, the flow of the NAUC slows and the flow bed widens. Subsequently, it upwells along the 3,500 km of coastal area from A Coruña (NW Spain) to Dakar (NW Africa). In the abyssal oceans, the mixing of water is relatively weak and intermittent, driven by double diffusive convection (DDC). The phenomenon known as salt fingering is typical for the DDC. However, the DDC is vigorous where the temperature difference between warm water and the cold water below is great, like in the confluence of the Brazil vs. Malvinas currents. Then salt fingers which are several hundred meters deep and several hundred kilometres wide are formed. In these salt fingers, the water of the warm current downwells and the water of the cold current upwells. This slows down the horizontal movement of the water molecules in both currents.
\end{abstract}

Keywords Brine Ejection from Ice, Downward Thrust of Descending Salty Water, Suction of the Gulf Stream, North Atlantic Undercurrent, Double Diffusive
Convection, Salt Fingering, Confluence of Brazil and Malvinas Currents

\section{Introduction}

Warm surface and cold undercurrents neutralize the temperature difference between the oceans and adjacent continental areas. A typical oceanic-atmospheric phenomenon is the desiccation of the nearby continental climate by the upwelling waters of the cold undercurrents. Typical biological phenomena include the abundant marine habitats due to the high nutritional value of the upwelled waters.

In the equatorial Atlantic Ocean, over a distance of 4,500 $\mathrm{km}$, trade winds create a constant pressure gradient which induces the westward flowing North Equatorial (NEC) and South Equatorial (SEC) currents. Those currents are the backbone of the water circulation in the Atlantic Ocean.

In the North Atlantic Ocean there is a major clockwise circulation or "gyre" of surface currents. In the South Atlantic Ocean, there is a counter-clockwise surface gyre, the southern branch of which is the South Atlantic Current (SAC). These "anticyclonic" circulations dominate the low- and mid-latitude portions of the Atlantic Ocean [1].

The major warm surface current induced by the NEC is the Gulf Stream and by the SEC the Brazil (BraC) and North Brazil (NBC) Currents. Especially important in the North Atlantic Ocean is the warmth carried by the Gulf Stream. In Finland, the basic school textbooks say that the Gulf Stream brings warmth to the British Isles, Nordic Countries, Iceland, Kuola Peninsula, Svalbard and the coasts of southern Greenland. In more explicit analysis, this route is divided into several interconnected chains of currents (Gulf Stream Currents, GSC), each of which have a name of its own. In this context, the Gulf Stream is only a small, but still important part of the chain. 
Specifically, the known major cold undercurrents are the East Greenland (EGC), Labrador (LabC) and Canary (CanC) currents in the North Atlantic and the Benguela (BenC) and Malvinas (MalC) currents in the South Atlantic.

Rather than being part of the North Atlantic surface gyre, the EGC and LabC are thought to be connected via the Deep Western Boundary Current (DWBC) to a separate Deep Conveyor Belt gyre, which is supposed to flow at a depth of several kilometers in ocean basins [2]. This theory does not explicitly explain how the NEC and SEC receive the compensating water for their continuous flow. The MalC is thought to form a gyre more or less of its own [3].

At present, there are three different formation mechanisms for the descending salty water (DSW). In the North Atlantic Ocean, it is presumed that warm surface water carried by the GSC upon cooling becomes denser and would then descend, forming the North Atlantic Deep Water (NADW). In the Southern Ocean, the brine ejection from ice is understood to produce dense water which descends as the Antarctic Bottom Water (AABW). In the North Pacific Ocean, it is supposed that because of the low salinity of the surface water no DSW forms at all [4]. On the other hand, it is known that the seawater freezes during winter in the North Atlantic, the North Pacific [5], and the Southern Ocean. It is not logical to suppose that brine would not be ejected from the ice in the North Atlantic and North Pacific Ocean.

An enigmatic issue is also the flow route of the DSW in the North Atlantic Ocean. It is suggested that the DWBC would convey the DSW (or in this case specifically the NADW) to the South Atlantic, and finally it would upwell into the Antarctic Circumpolar Current (ACC) [6].

The evidence of the existence of the DWBC flow route is based on measurements of chlorofluorocarbons (CFC), such as CFC-11 and CFC-12, in the seawater. These compounds are thought to be good tracers because they become incorporated into the deep water when it is renewed from the surface [7-9]. However, CFC are considerably denser than the water [10-11], due to which they descend in the oceans [12]. The density difference is so great that the CFC can descend to the bottom of the oceans with gravitation only. It is obvious that $\mathrm{CFC}$ measurements do not necessarily pinpoint the route of the DWBC. Instead, they show that CFC actually descend in the oceans at a considerable speed.

No driving forces along the presumed 12,000 km long route of the DWBC into the Southern Ocean can be presented. There needs to be an explanation other than the DWBC for the flow of the Arctic DSW in the North Atlantic Ocean.

The Arctic Ocean includes the deep central basin areas and the shallow coastal seas, Norwegian, Barents, Beaufort, Chukchi, East Siberian, Laptev, Greenland and Kara seas, Baffin Bay and the waters of the Canadian Arctic Archipelago (CAA).

The proportion of continental shelf to Arctic Ocean surface area is significantly greater than in any other ocean. The continental shelf comprises slightly more than half of the Arctic Ocean area over which most of the ice is annually freezing and melting. Subsequently they are significant producers of the DSW, which at first flows hundreds of kilometers along the bottoms of shallow coastal seas, where it acquires much nutritional value for the phytoplankton in the upwelling coasts.

The outflow routes of undercurrents from the Arctic Ocean are restricted to the CAA waters and the Davis Strait, the Fram Strait between Svalbard and Greenland, the Strait of Denmark between Greenland, troughs in the IcelandFaroe Islands-Scotland ridge and the Bear Island channel between the Barents and the Norwegian Seas.

Double diffusion convection (DDC) is a fluid dynamics phenomenon in instances where warm water lies above cold. DDC occurs because the heat and salt are subjected to unequal vertical transport. The molecular diffusivity for heat is approximately $10-3 \mathrm{~cm} 2 \mathrm{~s}-1$ and for salt approximately $10-5 \mathrm{~cm} 2 \mathrm{~s}-1$ [13-14]. DDC is studied in the middle depths $(1,000$ to $1,500 \mathrm{~m})$ in the central North Indian and North Atlantic Oceans. There the temperature difference is small, and DDC creates weak stratified turbulences.

In the confluence of $\mathrm{BraC}$ vs. MalC, warm surface current flows above cold undercurrent. The temperature difference between warm and cold water is great. The vertical movement of the waters by DDC is expected to be vigorous. The role of DDC in the observed changes in the flows of the currents after the confluence needs to be clarified.

\section{Materials and Methods}

\subsection{Aims of the Study}

The aims of this meta-study are as follows: (1) apply basic ice physics to calculate the annual amount of DSW formed by brine ejection from ice in the Arctic/Southern Oceans and the formation of undercurrents thereof, (2) calculate the thrust of the DSW as a driving force of the cold undercurrents, (3) apply the basic laws of hydraulics, Pascal's law of transmission of fluid pressure and Bernoulli's equation of fluid dynamics to understand the flow mechanisms of cold undercurrents, (4) clarify the importance of DDC in the generation of the salinity profiles of oceans (5) understand mechanisms in confluences of warm surface vs. cold undercurrents, and (6) demonstrate that upwellings are important indicators of cold undercurrents. The study is based on the available data in the literature on ocean currents and on DDC.

\subsection{Formulas Used in Calculations}

2.2.1. Calculation of the Annual Formation of the DSW in the Arctic and Southern Oceans 
The amount of DSW by brine ejection from the ice is calculated by the following proportion (1):

$$
\frac{a}{b}=\frac{c}{d}
$$

where $a$ is the salt increment which causes the sinking of $b$ $(=1 \ell)$ of surface water, $c$ is the total amount of salt ejected and $d$ is the annually formed amount of DSW in cubic meters.

The increment $a$ is the difference of the salt concentration of the surface water at the moment when DSW starts to descend (34.75\% and 34.62\%), and the salt concentration just before the freezing starts $(32.5 \%$ and $33 \%$ ) for the Arctic and Southern Oceans, respectively.

For calculating $c$, the residual salt concentration in the one-year-old ice is assumed to be $6 \%$. The annual area of the sea ice is $9,100,000 \mathrm{~km}^{2}$ and $15,700,000 \mathrm{~km}^{2}$, and the thickness of the ice $2 \mathrm{~m}$ and $1 \mathrm{~m}$ in the Arctic and Southern Oceans, respectively. The density of the ice is assumed to be $0.91 \mathrm{~kg} / \mathrm{m}^{3}$ and the effective freezing time 6 months (see Section 3.4.2 for the argumentation behind the selected values).

\subsubsection{Calculating the Thrust/Suction Created by DSW}

The Sverdrup (Sv) is used as the volume transport unit of the flow of an ocean current. One $\mathrm{Sv}$ is $10^{6} \mathrm{~m}^{3} / \mathrm{s}$. In calculating the thrust created by DSW in the Arctic and Southern Oceans, the flow of DSW in Sv is converted to kilograms. The product is divided by the maximum ice-covered area of the particular ocean $\left(15,600,000 \mathrm{~km}^{2}\right.$ in the Arctic and $18,800,000 \mathrm{~km}^{2}$ in the Southern Ocean) in square meters to yield the pressure in technical atmospheres $\left(\mathrm{kg} / \mathrm{m}^{2}\right)$. The quotient is converted to $\mathrm{N} / \mathrm{m}^{2}$ by the calculator [15].

\subsubsection{Newton's First Law of Motion (the Law of Inertia)}

Newton's first law states that an object at rest will stay at rest and an object in motion will stay in motion with the same speed and direction unless acted upon by unbalanced force. In the boreal/austral summers, only little water freezes in the Arctic and Southern Oceans. Then brine ejection from ice is at its minimum. Due to the inertia the outflow continues, though the flow volumes are then smaller. This causes fluctuation in the outflow of the undercurrents. In the calculation of the thrust/suction created by DSW, this decrease is estimated to be $30 \%$.

\subsubsection{Basic Laws of Hydraulics}

The flow of a deep-sea current obeys Pascal's law, according to which any force applied to a confined fluid is transmitted uniformly in all directions throughout the fluid regardless of the shape of the container (see Figure 1). It is important to note that (1) fluid pressure cannot be created without resistance to flow, and (2) Pascal's law is independent of the shape of the container, it is not necessary that the tube connecting the two pistons have the same cross-sectional area. A connection of any size, shape, or length will do, as long as an unobstructed passage is provided [16]. Upwellings provide an unobstructed passage for the continuous flow of an undercurrent.

The dynamics of the flow of an individual line of water molecules (a streamline) is described with Bernoulli's equation, which states that along any streamline, the sum of the density of kinetic energy, density of potential energy and pressure is a constant (see Equation 2) [17]:

$$
1 / 2 \rho v^{2}+\rho g z+\rho=\text { Constant }
$$

where $\rho$ is the density and $v$ the speed of the fluid at the height $\mathrm{z}$ and $\mathrm{g}$ is the force of the gravity.

In order for the quantity $\left(1 / 2 \rho v^{2}+\rho g z+\rho\right)$ to remain constant along the streamline, the water molecules need to trade speed for height or for pressure. In the open sea this is presumed to lead to slowing of the speed as well as widening of the flow bed along the route of the undercurrent before it is upwelling.

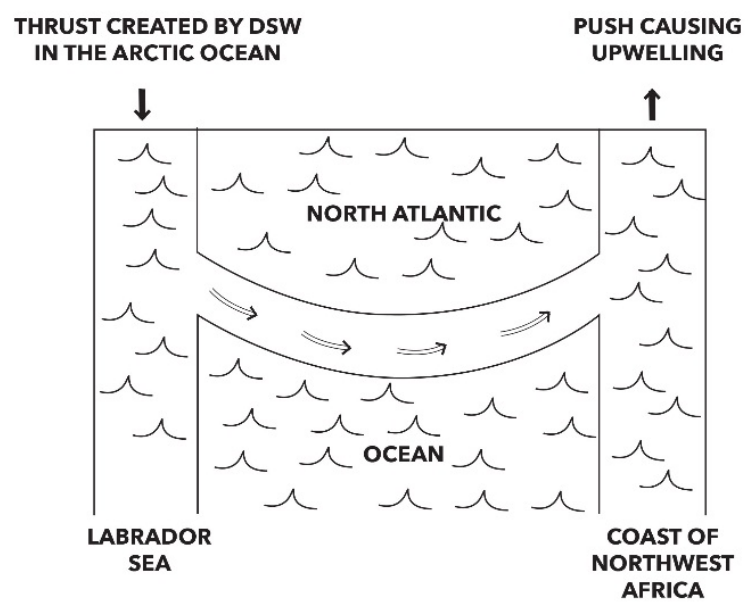

Figure 1. Schematic presentation of how the deep-sea current functions according to Pascal's law in the North Atlantic Ocean. Connected water in the Labrador Sea rises to the same depth in the coast of Northwest Africa.

\subsubsection{The DDC}

The density of the seawater is determined by a calculator [18], which takes into account the pressure effect as well. The decibar is used as the basic pressure unit, where 1 decibar is equal to 0.1 atmosphere.

The DDC is considered in three instances: (1) In the absence of turbulence and small temperature difference $(\Delta \mathrm{T})$ between the warm water and the underlying deep water, (2) in the presence of turbulence and small $\Delta \mathrm{T}$, and (3) in the presence of turbulence and large $\Delta \mathrm{T}$.

\section{Discussion}

\subsection{Double Diffusive Convection (DDC)}

\subsubsection{DDC in the Absence of Turbulence and Small $\Delta \mathrm{T}$}

The theory of the importance of DDC in abyssal waters 
was understood by research conducted in the northern Indian Ocean. At depths of 1,000 to $1,500 \mathrm{~m}$, salty and warm overflow waters from the Persian Gulf and Red Sea lie over the colder, less salty water [1].

The upper layer loses heat and the lower layer gains it. The upper water becomes denser and tends to sink and the lower layer becomes less dense and tends to rise. The driving force in DDC is the hundredfold difference in molecular diffusion rates between heat and salt. Vertical mixing occurs, which is also called salt fingering. The $\Delta \mathrm{T}$ is rather low, the basic requirement for the DDC at those depths is the absence of other kinds of turbulence.

The vertical scale of the salt fingers varies between 5 and $100 \mathrm{~m}$, and their typical horizontal scale is on the order of $10 \mathrm{~km}$. Due to the low $\Delta \mathrm{T}$, the formation of the salt fingers is a slow process. The lateral diffusion between the fingers, which gives rise to a uniform layer, is much slower than the vertical mixing. In a vast majority of the ocean's volume, the interior mixing of water is believed to be relatively weak and intermittent, driven by DDC [14].

If cool, less saline water lies over the warm, more saline water, the system is in static equilibrium. Again, assuming that turbulence may be neglected, the upper (cool) layer will gain heat from the lower (warm) layer by molecular diffusion without getting much salt and so becomes less dense and parcels of water will tend to rise within the upper layer. As the lower layer loses heat through the interface but not much salt, it becomes denser and water tends to sink, again with its own layer. The difference from the previous case is that fluid does not cross the interface water stays within its own layer, mixing and carrying heat up or down respectively [14].

\subsubsection{Importance of DDC in the Salination of Abyssal Waters}

Water is slightly compressible. If it were incompressible, each cubic centimeter of water in the water column would expand, and density values at all depths would be equal. If the average pressure occurring at a depth of $4,000 \mathrm{~m}$ (the approximate mean depth of the ocean) was somehow replaced with the average pressure that occurred at 2,000 $\mathrm{m}$ and the area of the oceans remained constant, there would be an average sea level rise of about $36 \mathrm{~m}$. Pressure in the abyssal waters is tremendous [19].

At present, the salinities at $2,000 \mathrm{~m}\left(4^{\circ} \mathrm{C}\right)$ and $4,000 \mathrm{~m}$ $\left(2{ }^{\circ} \mathrm{C}\right)$ in the equatorial Pacific Ocean are $34.64 \%$ and $34.69 \%$, in the equatorial Indian Ocean they are $34.74 \%$ and $34.72 \%$, and in the equatorial Atlantic Ocean 34.95\% and $34.86 \%$, respectively. The salt fingers in the vertical cross sections of the three major oceans are clearly perceptible [20].

At a depth of $4,000 \mathrm{~m}$ with the salinity of $34.95 \%$ and a temperature of $2{ }^{\circ} \mathrm{C}$, the density of the seawater is $1,045.98$ $\mathrm{kg} / \mathrm{m}^{3}[18]$. Then the salinity of the surface water needs to be $57.4 \%$ in order for it to descend by gravity alone to a depth of $4,000 \mathrm{~m}$. Such a high-salinity surface water is not formed anywhere in the major oceans or even in the Mediterranean seas. DDC is a necessary mechanism for carrying salty water downwards for the development of the salinity profiles of the oceans.

Assuming 4 billion years as the average age of the oceans [21] and $34.75 \%$ as the present average salinity of the abyssal waters, an increase of $1 \%$ in the salinity would need 106 million years. For the density, the pressure is a more important factor than the salinity in the abyssal waters. As the lateral diffusion between the salt fingers is much slower than the vertical diffusion, it can be concluded that in the abyssal waters the density differences are an infinitely small driving force for a deep-water current. Different salination profiles of the North and South Atlantic Oceans [20] show that their middle depth and abyssal waters do not communicate with each other.

The ventilation of the abyssal waters from the surface is a slow process. At the sea bottoms, thousands of black smokers constantly and hundreds of volcanoes frequently eject fresh water, and large-scale seismic activities (earthquakes, tsunamis and subductions) are stirring the water columns of the oceans. It is likely that the ventilation takes place from below as well.

\subsubsection{DDC in Turbulent Conditions and Small $\Delta \mathrm{T}$}

Between the latitudes of $15^{\circ} \mathrm{N} /{ }^{\circ} \mathrm{S}$ to $30^{\circ} \mathrm{N} /{ }^{\circ} \mathrm{S}$, evaporation in the oceans is the highest [22]. The salt content of the surface water may be even 37\% [23]. At a temperature of $25{ }^{\circ} \mathrm{C}$, the density of the surface water is $1,024.86 \mathrm{~kg} / \mathrm{m}^{3}$. At the same time, at a depth of $100 \mathrm{~m}$ the temperature is approximately $16^{\circ} \mathrm{C}$, the salinity of water is $35 \%$ and the density $1,025.71 \mathrm{~kg} / \mathrm{m}^{3}$, greater than that of the surface water [18].

In the Northern Atlantic Ocean (south of $65^{\circ} \mathrm{N}$ and west of $23^{\circ} \mathrm{W}$ ), the water brought by the GSC (the Irminger Current) is cooled to approximately $7^{\circ} \mathrm{C}$ to $8^{\circ} \mathrm{C}$, having a salinity of $35.2 \%$ [24]. The density of the water is $1,027.43$ $\mathrm{kg} / \mathrm{m}^{3}$. At a depth of $100 \mathrm{~m}$, the temperature is approximately $5{ }^{\circ} \mathrm{C}$ and the salinity $35.0 \%$. Its density is $1,028.14 \mathrm{~kg} / \mathrm{m}^{3}$, greater than that of the surface water.

Further north and east, in the Norwegian Sea, the surface temperature of the water brought by the GSC (the West Spitsbergen Current) is cooled to approximately $5{ }^{\circ} \mathrm{C}$, with a salinity of $34.5 \%$. At a depth of about $100 \mathrm{~m}$, the temperature is approximately $2{ }^{\circ} \mathrm{C}$ to $3{ }^{\circ} \mathrm{C}$ and the salinity 34.7 to $34.8 \%$ [24]. The surface water cannot descend.

It is clear that in the unfrozen sea conditions mere cooling does not increase the density of the water enough that the water would sink in the North Atlantic Ocean by gravity alone. The $\Delta \mathrm{T}$ between the surface water and the water below to a depth of $100 \mathrm{~m}$ is so small that turbulence in the unfrozen sea prevents DSW formation by the DDC mechanism as well.

\subsubsection{DDC in Turbulent Conditions and Large $\Delta \mathrm{T}$}

Along the eastern coast of South America, the warm 
$\left(20{ }^{\circ} \mathrm{C}\right.$ to $\left.23{ }^{\circ} \mathrm{C}\right)$ south-flowing Brazil Current $(\mathrm{BraC})$ meets the cool $\left(6^{\circ} \mathrm{C}\right)$ north-flowing Malvinas (Falkland) Current (MalC). As a clearly identified current, the BraC flows up to $35^{\circ} \mathrm{S}$ until it reaches the MalC offshore the Rio de la Plata estuary [25]. According to the satellite visual wavelength and IR images, the confluence is vigorous between $37^{\circ} \mathrm{S}$ and $39^{\circ} \mathrm{S}$ [26]. In the confluence the $\Delta \mathrm{T}$ is so great that, in addition to salt fingers, temperature fingers are clearly observable [27] (See Figure 2). Due to the great $\Delta \mathrm{T}$, the salt and temperature fingerings are so vigorous that they overcome the turbulence in the upper $100 \mathrm{~m}$.

According to the $8{ }^{\circ} \mathrm{C}$ isotherm contours, the confluence is discernable even at $45^{\circ} \mathrm{S}$. [28]. As at $37^{\circ} \mathrm{S}$, one degree of longitude equals $88 \mathrm{~km}$, the confluence zone is $1,300 \mathrm{~km}$ wide at $37^{\circ} \mathrm{S}$ (see Figure 3). The MalC splits the BraC into two contours starting at south of $36^{\circ} \mathrm{S}$ between longitudes $44^{\circ} \mathrm{W}$ to $46^{\circ} \mathrm{W}$. At around $38^{\circ} \mathrm{S}$, the southern branch of the eastern contour starts to turn east (see Figure 3). This $38^{\circ} \mathrm{S}$ branch is the beginning of the South Atlantic Current (SAC).
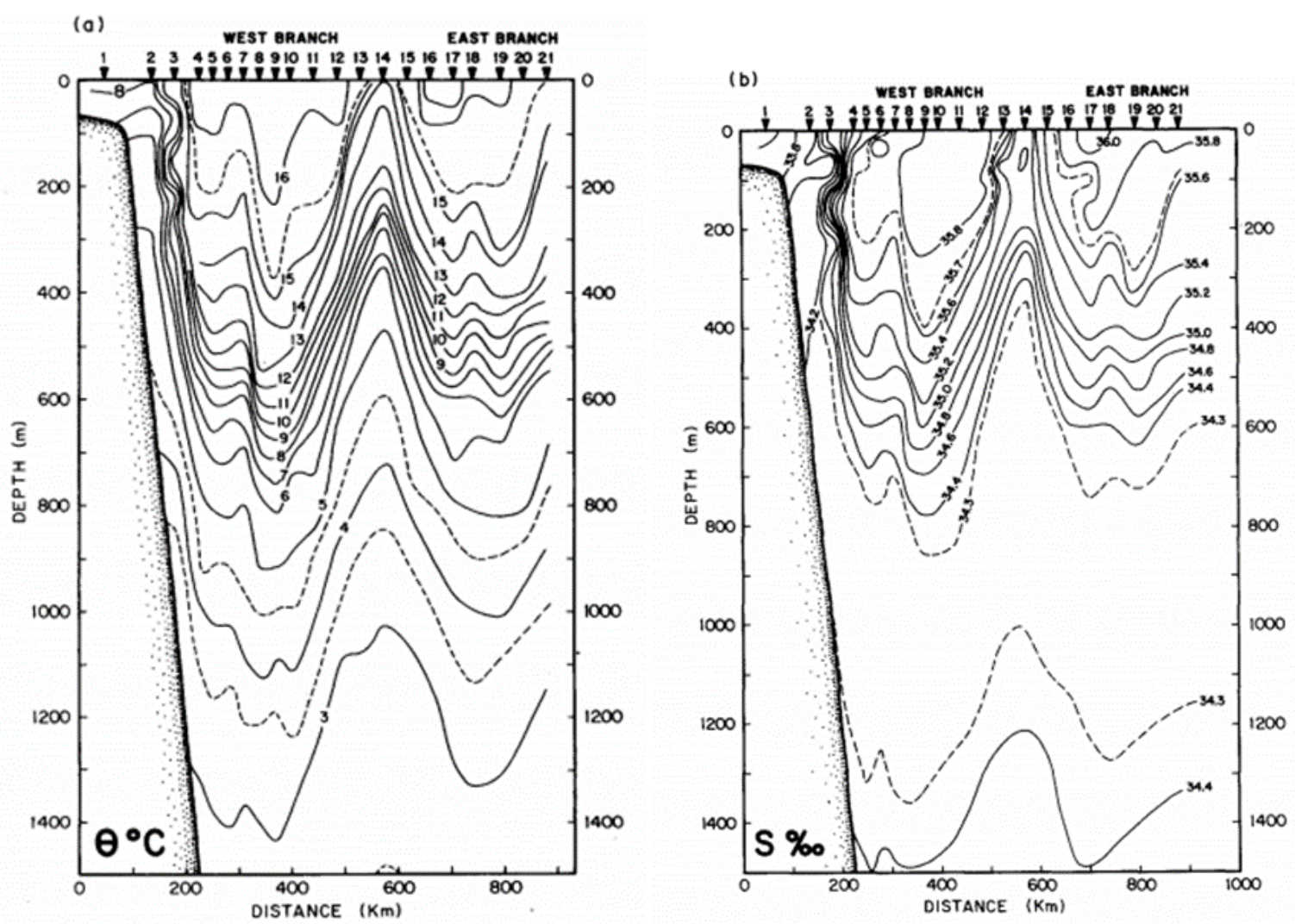

Figure 2. Temperature (a) and salt (b) fingers in the confluence of $\mathrm{BraC}$ vs. MalC [27]. West and east branch in this figure are actually subbranches of the major western contour in the Figure 3 


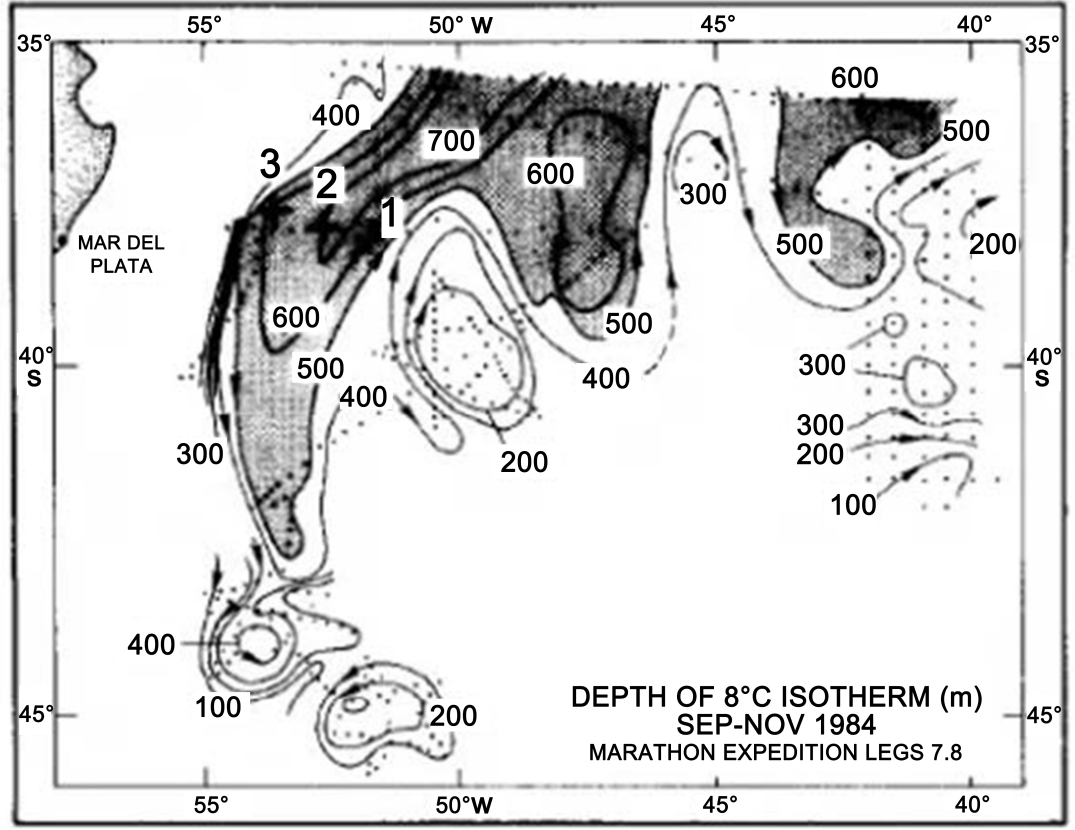

Figure 3. Depth of $8{ }^{\circ} \mathrm{C}$ isotherm showing two major contours when $\mathrm{MalC}$ is splitting the $\mathrm{BraC}$ along the 44 to $46^{\circ} \mathrm{W}$ in the Argentine $\mathrm{Basin}$ during the austral spring of 1984 [28]

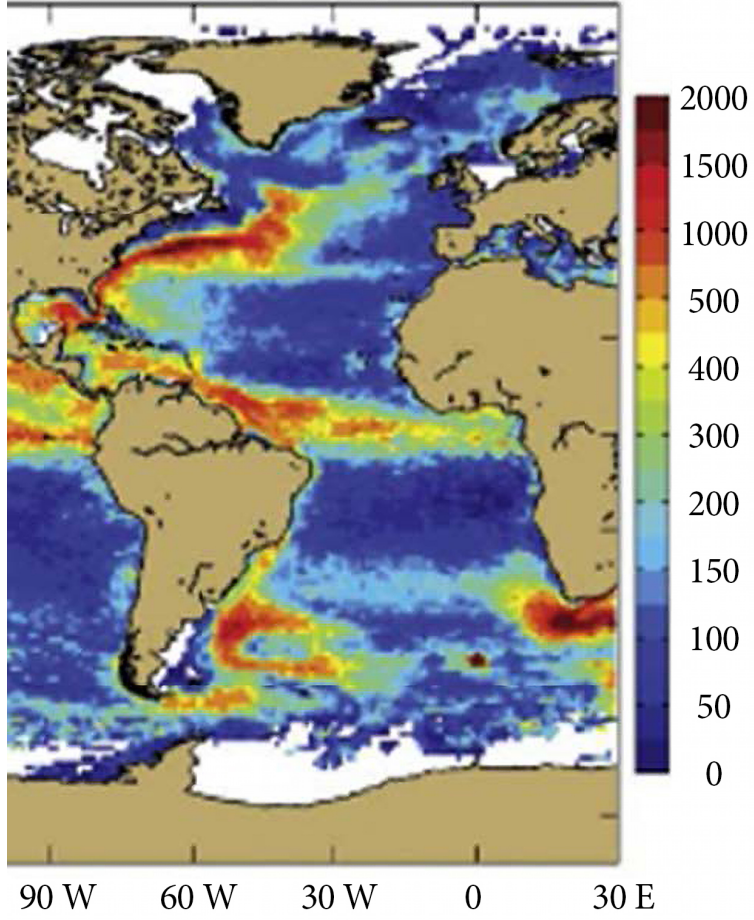

Figure 4. Eddy kinetic energy chart $\left(\mathrm{cm}^{2} / \mathrm{s}^{2}\right.$, between $30^{\circ}$ to $\left.55^{\circ} \mathrm{W}\right)$ showing two retroflected surface currents at $40^{\circ} \mathrm{S}$ (SAC) and $50^{\circ} \mathrm{S}$ formed in the confluence of the $\mathrm{BraC}$ and $\mathrm{MalC}[30]$.

The western contour is split by the MalC south of $38^{\circ} \mathrm{S}$ between longitudes of $48^{\circ} \mathrm{W}$ to $52^{\circ} \mathrm{W}$ into two subbranches from which the western one at first continues its flow south. At around $45^{\circ} \mathrm{S}$ and between longitudes of $50^{\circ} \mathrm{W}$ to $55^{\circ} \mathrm{W}$ it starts to turn east, forming the $50^{\circ} \mathrm{S}$ current which eventually joins the ACC (see Figure 4).

In the confluence two eastbound surface currents are formed, one around $38^{\circ} \mathrm{S}$ and the second around $50^{\circ} \mathrm{S}$ [29]. These two currents are clearly depicted in the eddy current chart (see Figure 4).

The salt fingers of the subbranches extend to a depth of $600 \mathrm{~m}$ to $800 \mathrm{~m}$ and are $200 \mathrm{~km}$ to $300 \mathrm{~km}$ wide (see Figure 2) [27]. In the salt fingers, the $\mathrm{BraC}$ water downwells and that of the MalC upwells. The mixing of the water molecules is uneven. Because both the SAC and the $50^{\circ} \mathrm{S}$ currents are initially flowing to south, it is obvious that the momentum of the $\mathrm{BraC}$ water is then commanding the direction of the movement. The $50^{\circ} \mathrm{S}$ current contains more of the $\mathrm{BraC}$ water because the momentum of the MalC water is more slowly diverting the flow east than in the case of the SAC.

In the confluence zone horizontal movements of water molecules in both of the participating currents are slowed by the vertical movement in the salt fingers. South of $40^{\circ} \mathrm{S}$ between longitudes 44 to $46^{\circ} \mathrm{W}$ the eastern subbranch fades out (see Figure 3). One reason may be that the down- and upwellings of the $\mathrm{BraC}$ and $\mathrm{MalC}$ water molecules are ceased, and their horizontal speeds are slowed to the point that they are not distinguished from the ambient sea water molecules by their momentum.

In the gap between the eastern and western contours at 44 to $46^{\circ} \mathrm{W}$ (see Figure 3), the mixing of the MalC water with the above flowing BraC water is ceased. The deep core of the MalC water in the gap encounters no further stress by the $\mathrm{BraC}$ watere and keeps on flowing north more or less untouched.

The more the $\mathrm{BraC}$ molecules descend in the salt fingers, 
the more their horizontal (and vertical) movements decrease. It is likely that under the salt fingers, the $\mathrm{BraC}$ water is already at a stillstand or close to it. When mixing, the direction of the momentum of the deep core MalC water does not change. It continues to flow north there as well.

The deep convections at $34.5^{\circ} \mathrm{S}$ described by Meinen et al. (2017) [31] may be due to the turbulence and shear that the northbound MalC deep core causes downwards.

\subsection{Equatorial Ocean Currents}

\subsubsection{The NEC and SEC}

All three major oceans have similar equatorial current systems consisting of westward flowing SEC at or south from the equator and a westward flowing NEC north from equator. The Atlantic NEC is found between about $10^{\circ} \mathrm{N}$ and $20^{\circ} \mathrm{N}$, and the SEC between the latitudes of about $0^{\circ}$ and about $20^{\circ} \mathrm{S}$ [32]. Both begin from the western coast of Africa (See Figure 5).

The Brazilian coast diverts at $6^{\circ} \mathrm{S}$ to $8^{\circ} \mathrm{S}$ the northern branch of the SEC (nSEC) north forming the main part of the North Brazil current (NBC) [33]. The southern branch of the SEC (sSEC) bifurcates south as the Brazil Current (BraC) and north contributing to the NBC [34]. The bifurcation axis migrates from $10^{\circ} \mathrm{S}$ in November to $14^{\circ} \mathrm{S}$ in July [35].

Between the NEC and SEC is created a space, which tends to be void of downstream-flowing water. The NEC and SEC can be taken as separate bundles of westward streamlines of water. Between them forms an eastward bound streamline. One reverse flow is on the surface, the North Equatorial Countercurrent (NECC), and one is in the deeper water, the North Equatorial Undercurrent (NEUC). An important additional driving force of NECC and NEUC is the suction caused by the removal of the water from the starting points of the NEC and SEC. In the Atlantic, the NECC is year-round significant only in the eastern part.

In the Pacific Ocean the Equatorial Countercurrent is very strong and it is definable north of the equator year-round. In the Indian Ocean, the three-current pattern is present for part of the year and a two-current pattern for the remainder. In summer the Indian Ocean NEC flows eastwards, when it is called the Indian Monsoon Current.

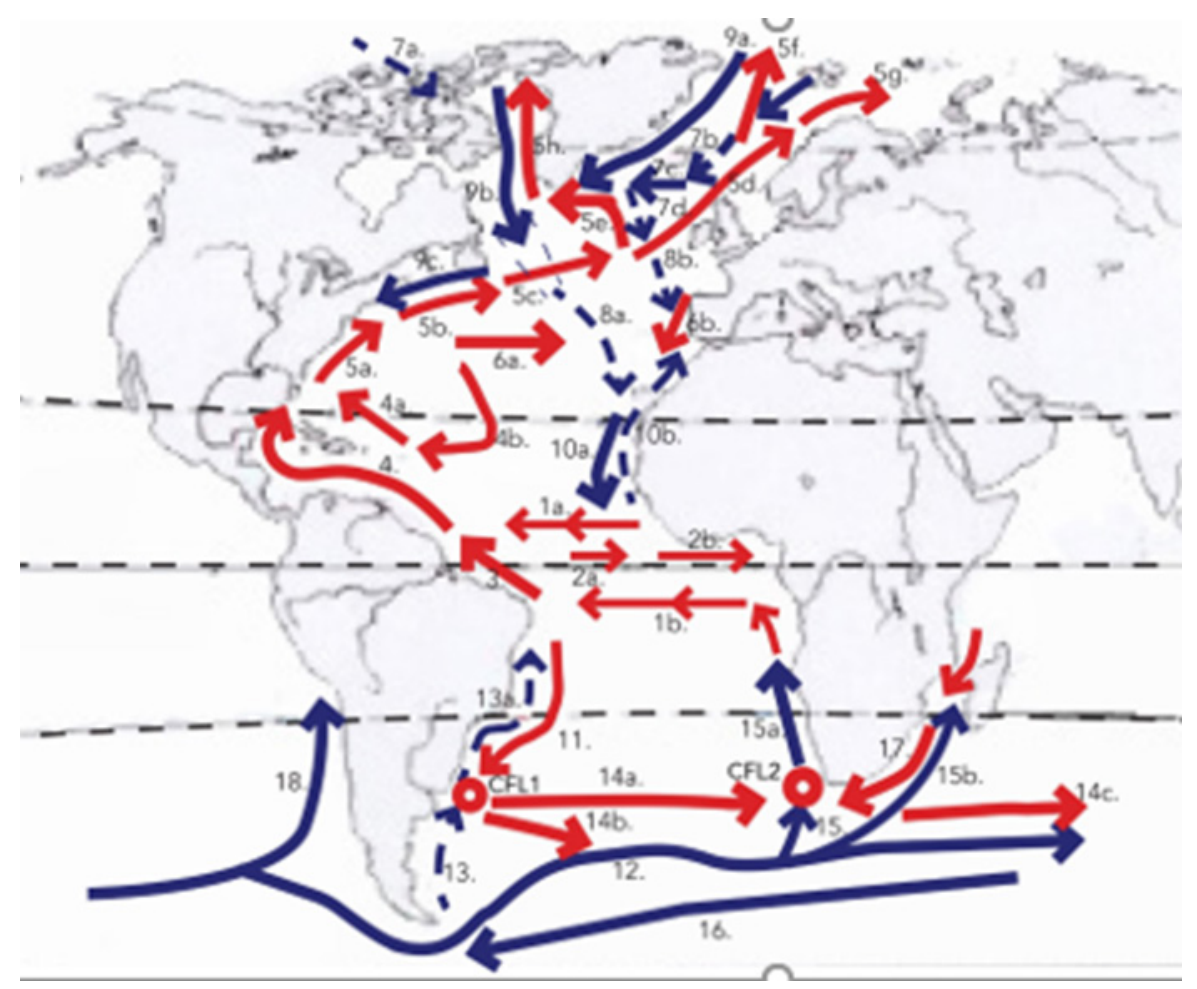

Figure 5. Major ocean currents in the Atlantic Ocean: $1 a=N E C, 1 b=$ SEC, $2 a=N E C C, 2 b=$ Guinea Current, $3=N B C, 4=$ Guiana and Caribbean Currents, $4 \mathrm{a}=$ Antilles Current, $4 \mathrm{~b}=$ Sargasso Sea recirculation, $5 \mathrm{a}=$ Florida Current, $5 \mathrm{~b}=$ Gulf Stream, $5 \mathrm{c}=\mathrm{NAC}, 5 \mathrm{~d}=\mathrm{NwAC}, 5 \mathrm{e}=\mathrm{IrmC}, 5 \mathrm{~g}=\mathrm{NCaC}$, $5 \mathrm{f}=\mathrm{WSC}, 5 \mathrm{~h}=\mathrm{WGC}, 6 \mathrm{a}=$ Azores Current, $6 \mathrm{~b}=$ Portugal Current, $7 \mathrm{a}=$ Beaufort Sea inflow, $7 \mathrm{~b}=\mathrm{BSUC}, 7 \mathrm{c}=\mathrm{BSUC} \mathrm{W}, 7 \mathrm{~d}=\mathrm{BSUC}_{\mathrm{s}}, 8 \mathrm{a}=\mathrm{NAUC}, 8 \mathrm{~b}$ $=$ NAUC, $9 \mathrm{a}=\mathrm{EGC}, 9 \mathrm{~b}=\mathrm{LabC}, 9 \mathrm{c}=\mathrm{LabC}_{\mathrm{S}}, 10 \mathrm{a}=\mathrm{CanC}, 10 \mathrm{~b}=\mathrm{PUC}, 11=\mathrm{BraC}, 12=\mathrm{ACC}, 13=\mathrm{MalC}, 13 \mathrm{a}=\mathrm{MalC}, 14 \mathrm{a}=\mathrm{SAC}, 14 \mathrm{~b}=50^{\circ} \mathrm{S}$ current, $14 \mathrm{c}=\operatorname{SIOC} 15 \mathrm{a}=\mathrm{BenC}, 15 \mathrm{~b}=$ BenC $_{\mathrm{E}}, 16=\mathrm{AnCoC}, 17=$ AguC, $18=$ Peru Current, CFL1 $=$ Confluence of BraC vs. MalC, CFL2 = Confluence of AguC vs. BenC. 
In the Indian Ocean, the countercurrent flows only during the boreal winter and only south of the equator. The undercurrent is only a seasonal feature [36].

The throughflow from the Pacific NEC via the Indonesian archipelago to the Indian Ocean is $13.5( \pm 6.6)$ Sv [37].

\subsubsection{The NECC and NEUC}

In the North Atlantic Ocean, from July to December the NECC flows continuously eastward between about $5^{\circ} \mathrm{N}$ and $8^{\circ} \mathrm{N}$, with an average speed up to $50 \mathrm{~m} / \mathrm{s}$. East of $20^{\circ} \mathrm{N}$ the flow continues throughout the year. In the austral summer, the intertropical convergence zone, the meeting line of the northeast and southeast trade winds, shifts equatorward.

Then, the winds along the equator relax. According to ship-drift records this takes place in the western equatorial Atlantic over a band of longitude from $23^{\circ} \mathrm{W}$ to $33^{\circ} \mathrm{W}$. This causes the seasonal disappearance of the NECC west of $20^{\circ} \mathrm{W}$ in January to June. A westward current is then observed [38].

The seasonal cycle of NECC is very regular. Each year it starts up in May and June and flows eastward across the Atlantic with surface speeds up to $143 \mathrm{~cm} / \mathrm{s}$ in the west, extending down to $350 \mathrm{~m}$ at $28^{\circ} \mathrm{W}$, and returning water for NEC and via the Guinea Current to SEC as well [39]. Part of the heat transported by the NBC is adding up to the NEC. This is a likely reason why the hurricanes are extremely rare in the South Atlantic basin.

The NEUC follows the cycles of the NECC. The maximum current speed of the NEUC is over $100 \mathrm{~cm} / \mathrm{s}$ during October and November at a depth of $80 \mathrm{~m}$. Between January and June the core of the NEUC gradually moves upward from $80 \mathrm{~m}$ to $60 \mathrm{~m}$.

\subsubsection{The Guinea Current}

Off the Ghanaian coast, the eastern part of NECC is also known as the Guinea Current (see Figure 5). Depending on the season, the primary source of water in the Guinea Current is either the Canary Current (CanC) or the NECC [40].

In April and May, at the end of the period when NECC disappears west of $20^{\circ} \mathrm{W}$, the contribution of the NECC in the Guinea Current is the lowest. The CanC contribution is then the highest. After that the contribution of the NECC starts to increase. However, due to the inertia, the increase is at first low, reaching its maximum in October and November, when the NEUC flow speed reaches its maximum as well.

In the boreal summer the flow of the CanC starts to increase (see section 3.5.6). For this reason, the CanC may maintain its relatively high contribution in the flow of the Guinea Current even during the boreal summer.

The northern Gulf of Guinea is known to host a coastal upwelling in boreal summer [41]. It is likely that the CanC causes this upwelling, and same time removing some of the water the NBC brings to the North Atlantic Ocean.

\subsubsection{NBC and Antilles Current}

During austral spring when the NECC disappears, the NBC continues to flow along the coast northwest as the Guiana Current. Then (during the boreal winter) the northward heat transport across $10^{\circ} \mathrm{N}$ is of the order of a peta-watt, [42]. This is called northern heat piracy [43]. The volume transport of South Atlantic Water to the North Atlantic is 7.5 Sv [44].

During austral fall, however, the whole NBC veers off the coast of French Guyana between $45^{\circ} \mathrm{W}$ and $50^{\circ} \mathrm{W}$, forming the western NECC [39]. Then, during the boreal summer, the northward heat transport is practically zero [42].

The NBC absorbs freshwater from the Amazon River as well, but it is still predominantly a saltwater current. Around $15^{\circ} \mathrm{N}$ the southern part of the NEC waters starts to join the Guiana Current as well. Between the Windward Islands, mainly via the Grenada and St Vincent Passages, the water flows as the Caribbean Current into the southern Caribbean [45]. Via the Straits of Yucatan, the Yucatan Current carries the water into the Gulf of Mexico. There the Loop Current connects the Yucatan Current and the Florida Current, which is also considered the beginning of the GSC.

\subsection{The Gulf Stream Currents}

\subsubsection{The Florida Current and the Gulf Stream}

The first current in the chain of the GSC is the north-northeastward Florida Current. From 1982 to 1984, its volume transport between West Palm Beach and Grand Bahama Island ranged from $20 \mathrm{~Sv}$ to $40 \mathrm{~Sv}$, with a mean of $30.5 \mathrm{~Sv}$. The annual cycle of the transport shows a broad maximum during spring and summer and then a sharp drop to a minimum in October. The amplitude of the volume transport is $3 \mathrm{~Sv}$ [46]. This is likely due to the retroflection of the NBC to the east as part of the NECC.

The northern part of the NEC continues as the Antilles Current northwest around the Bahamas, after which it is joined with the Florida Current (see Figure 5) [47]. This strengthens the flow of the Florida Current, and it also receives waters from the Sargasso Sea circulation. Subsequently, its volume transport is $93.7 \mathrm{~Sv}$ in Cape Hatteras. At the same time, the flow width gradually increases from $80 \mathrm{~km}$ to $145 \mathrm{~km}$ [48].

The Florida Current has a strong and rather narrow flow which creates a seasonally varying coastal countercurrent, an undercurrent jet attached to the Florida shelf, and an intermittent undercurrent on the Miami Terrace, all southward [49].

At around Cape Hatteras, the Florida Current diverts northeast as the Gulf Stream by that branch of the Labrador Current $\left(\mathrm{LabC}_{\mathrm{S}}\right)$ that is forced to flow southwest over the Grand Bank of Newfoundland (GBN) by the East Greenland (EGC) and the shelfbreak EGC (sEGC) currents (see section 3.5.4). Around $35^{\circ} \mathrm{N}, 55^{\circ} \mathrm{W}$, the Sargasso Sea 
recirculation branches from the Gulf Stream, and at around $40^{\circ} \mathrm{N}, 40^{\circ} \mathrm{W}$ the Azores Current does the same. On the GBN, the Gulf Stream mixes with surface waters of the North Atlantic Undercurrent (see sections 3.5.4 and 3.5.5) and the flow of the Gulf Stream is diverted east across the North Atlantic Ocean as the North Atlantic Current (NAC) (See Figures 5 and 6).

\subsubsection{The North Atlantic Current}

The NAC is also called the North Atlantic Drift. Westerlies, in addition to the suction created by the DSW in the Arctic Ocean, are driving forces for the NAC. At the beginning, the volume transport of the NAC is $35 \mathrm{~Sv}$, which on average equals that of the Florida current just after the Florida Strait.

When NAC is advancing further it diverts to the northeastern and eastern branch at around $50^{\circ} \mathrm{N}, 45^{\circ} \mathrm{W}$. At around $54^{\circ} \mathrm{N}, 26^{\circ} \mathrm{W}$, the Irminger Current (IrmC) branches north from the northeastward NAC. On the southwest coast of Ireland, the eastward NAC diverts northward, flowing through the Rockall and Faeroe-Shetland Channels. Locally, there is a 4 to $5 \mathrm{~Sv}$ flow in the Rockall Channel, a region of pervasive eddies, toward the Norwegian Sea [51] (see Figure 7).

According to sea-glider observations, the northeastern branch of the NAC flows approximately five hundred kilometers farther north than the eastern branch. Along $58^{\circ} \mathrm{N}$ and between $21^{\circ} \mathrm{W}$ and $15^{\circ} \mathrm{W}$ (over the Rockall Plateau), the annual mean northward transport of this branch of the NAC is $5.1 \pm 3.2 \mathrm{~Sv}$. During summer (May to October), the mean northward transport is stronger and reaches $6.7 \pm 2.6 \mathrm{~Sv}$ [52-53]. There may be other branches of the NAC as well because the flow across $59.5^{\circ} \mathrm{N}$ is reported to be $15.5 \pm 0.8 \mathrm{~Sv}$ east of the Reykjanes Ridge (RR) [54].

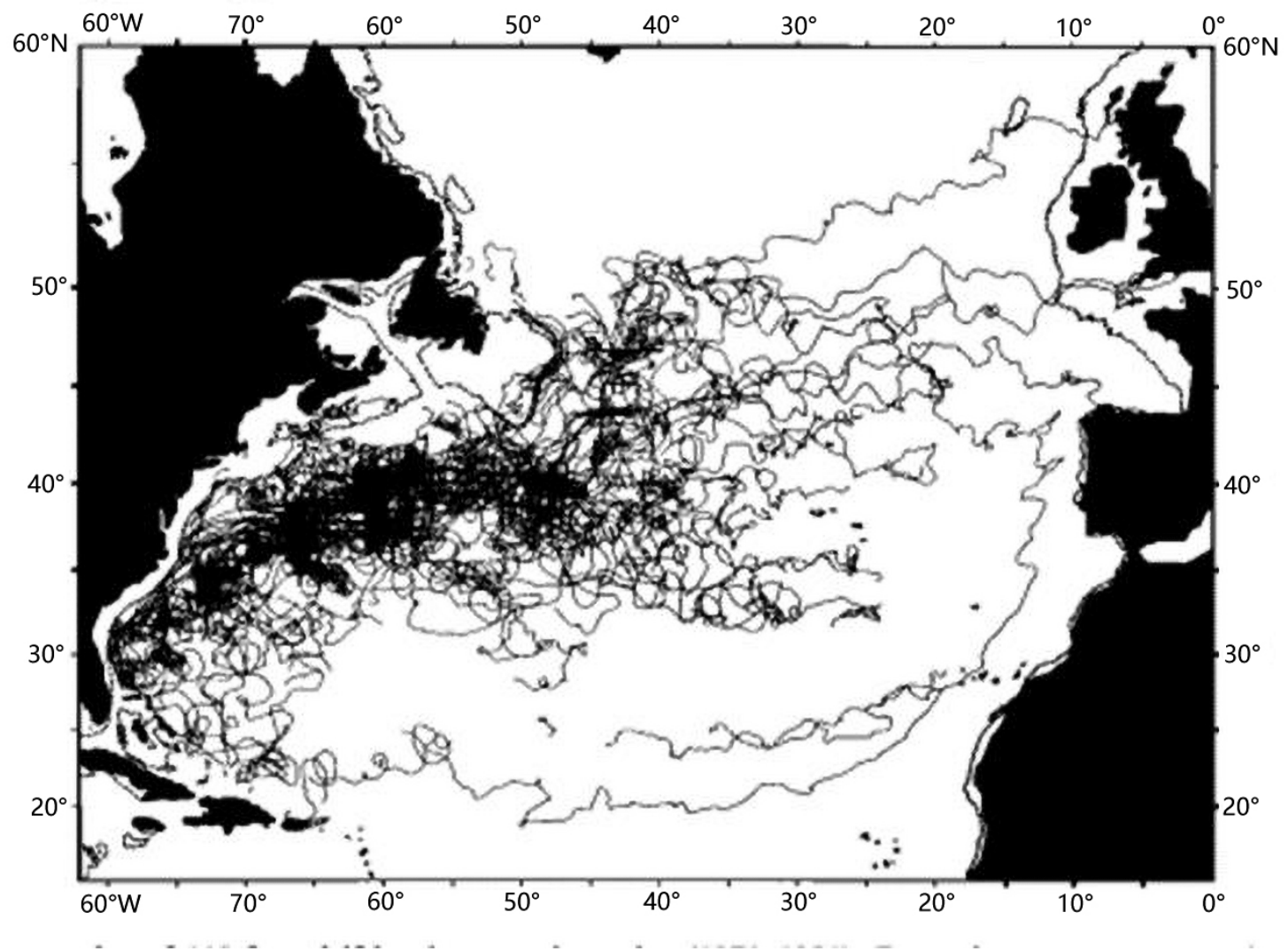

Figure 6. Summary plot of 110 free drifting satellite-tracked buoy trajectories (1971-1981) in the GSC. The branching of the Gulf Stream into the Sargasso Sea recirculation, Azores Current and North Atlantic Current is visible in the tracks east of $55^{\circ} \mathrm{W}-40^{\circ} \mathrm{W}$ [50]. 


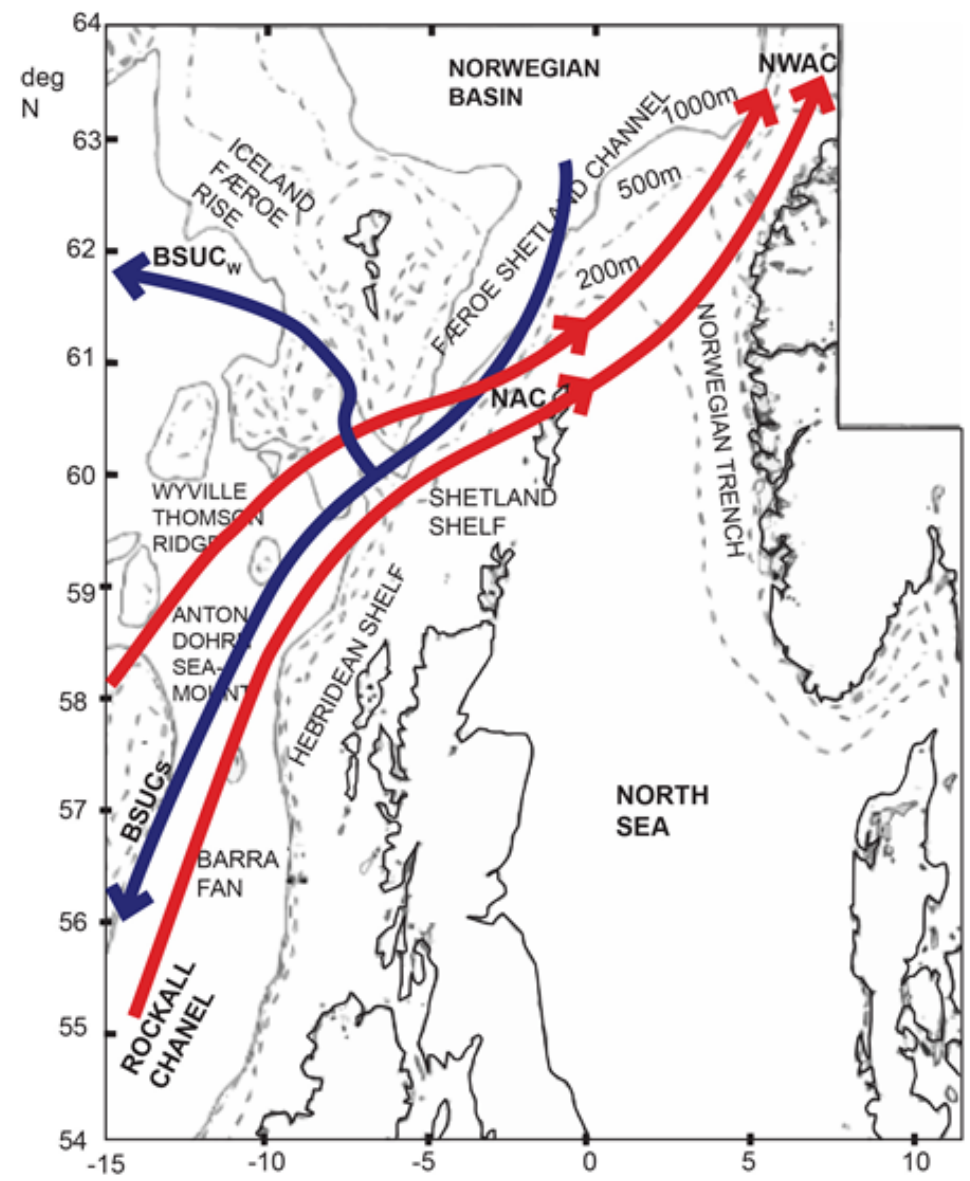

Figure 7. Route of NAC along the Rocknall channel drawn on the map from [51]

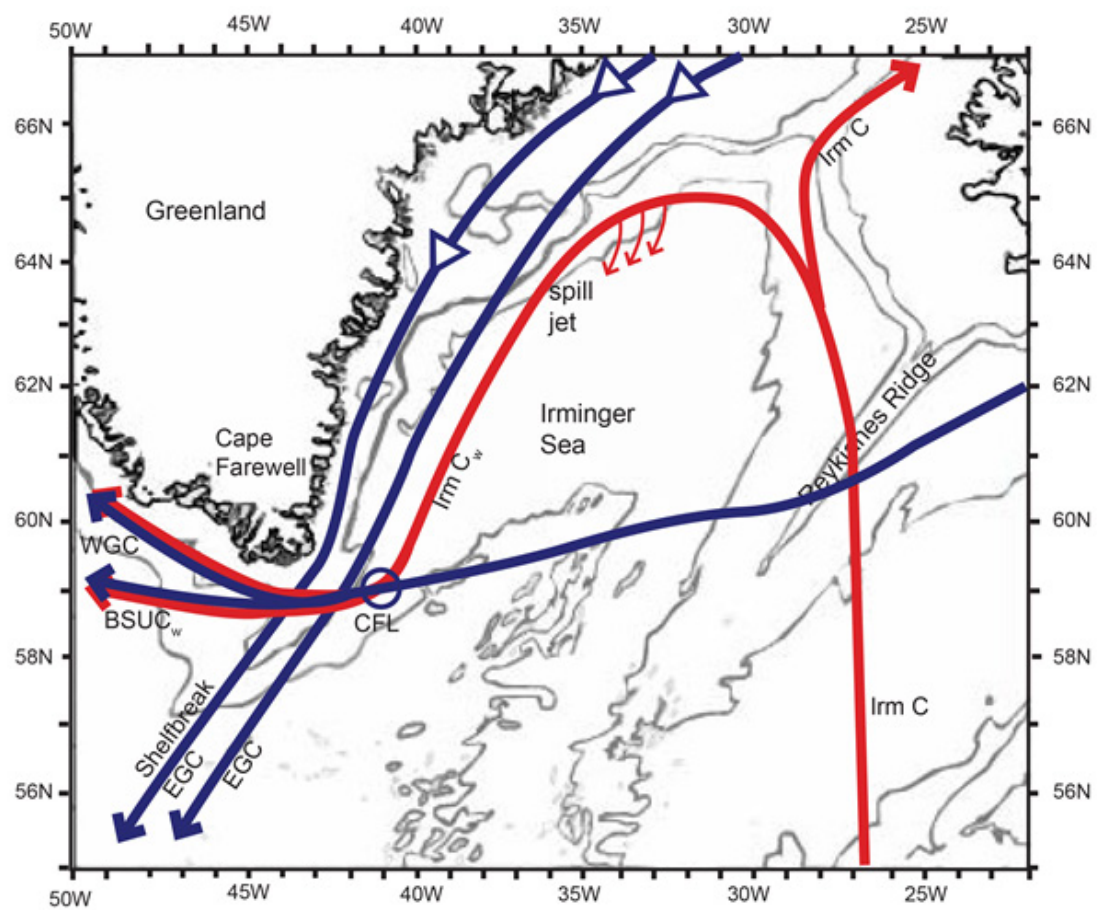

Figure 8. Route of IrmC, CFL = Confluence of $\operatorname{IrmC}_{\mathrm{W}}$ vs. BSUC $\mathrm{W}_{\mathrm{W}}$;.drawn on the map from [56] 


\subsubsection{The Irminger and West Greenland Currents}

The volume transport of the IrmC at the beginning is estimated to be $12 \pm 3 \mathrm{~Sv}$ [54]. The westbound branch $\mathrm{IrmC}_{\mathrm{W}}$ diverts off the western coast of Iceland. The northbound IrmC passes Iceland from the west and then turns east as the North Iceland IrmC (see Figure 8) [55].

The $\mathrm{IrmC}_{\mathrm{W}}$ flows into the Irminger Sea. There it turns southwest by the spill jet, which is a bottom-intensified phenomenon caused by the EGC [56] (see Figure 8).

From that point onwards southwest in the Irminger Sea flow codirectionally three currents: The $\operatorname{IrmC}_{\mathrm{W}}, \mathrm{EGC}$, and sEGC. The IrmC $C_{W}$ is hardly directly interacting with the EGC, as it is able to deliver some of the warmth to the West Greenland Current (WGC). Vertical and horizontal distances between the warm and cold water likely prevent DDC.

Dense Iceland-Scotland Overflow Water ISOW), brought by the western branch of the Barents Sea Undercurrent $\left(\mathrm{BSUC}_{\mathrm{W}}\right)$, also enters from the east to the Irminger Sea as well (see section 3.5.3). At Cape Farwell after the confluence with the $\mathrm{BSUC}_{\mathrm{W}}$, a portion of the $\mathrm{IrmC}_{\mathrm{W}}$ water flows northeast along the coast of western Greenland as the West Greenland Current (WGC) (see Figure 8).

The importance of the input of $\mathrm{IrmC}_{\mathrm{W}}$ water in the WGC is manifested in the Disko Bay. It is a sheltered, open embankment (approximately $150 \mathrm{~km}$ long and $100 \mathrm{~km}$ wide with an average depth of $400 \mathrm{~m}$ ) in central West Greenland. In winter the bay is characterized by a well-mixed water column with temperatures around $2{ }^{\circ} \mathrm{C}$, and by land-fast ice from December/January to March, which breaks up in spring (April to May). In the summer the surface temperature may reach $12{ }^{\circ} \mathrm{C}$ [57]. At the same time, on the other side of Baffin Bay, the water temperature is around zero degrees.

\subsubsection{The Norwegian Atlantic, West Spitsbergen and North Cape Currents}

At the level of the Svinøy lighthouse $\left(62.33^{\circ} \mathrm{N}, 5.27^{\circ} \mathrm{E}\right)$, the Norwegian Atlantic Current (NwAC) has an eastern and a western branch (representing the eastern and northeastern branches of the NAC), both with 30 to $50 \mathrm{~km}$ wide currents, which means that yearly the flow is $7.6 \mathrm{~Sv}$ [58]. (See Figure 7). The NwAC branches at about $67^{\circ} \mathrm{N}$, $3^{\circ} \mathrm{E}$ to the northbound West Spitsbergen Current (WSC) and eastbound North Cape Current $(\mathrm{NCaC})$ (see Figures 5 and 10) [59]. When arriving to Svalbard, the WSC volume transport is $1.3 \mathrm{~Sv}$ northward $\left(\right.$ at $\left.78^{\circ} \mathrm{N}\right)$. Near $80^{\circ} \mathrm{N}$, the WSC bifurcates to a westward branch, which joins the southward-flowing EGC, and an eastern branch, which transports about 20 percent of its initial flow into the
Arctic Basin. No northward flow of WSC water is observed along the western flank of the Yermak Plateau. A cyclonic recirculation of the eastern branch of the WSC has been observed east of the Yermak Plateau [60].

The $\mathrm{NCaC}$ keeps the coastline of the Kuola peninsula up to the Murmansk ice-free during the whole year. Its flow as a warm current (compared to the ambient cold water) can be identified up to the Laptev Sea (see Figure 10) [61].

According to a recent study, the throughflow in the Bering Strait is primarily driven from the Arctic to the Pacific Ocean, not vice versa [62]. The flow of the $\mathrm{NCaC}$ may continue as a cold current even through the Bering Strait, contributing to the outflow from the Arctic to the Pacific Ocean and removing some of the water the NBC brings to the North Atlantic Ocean.

\subsection{Formation of the Undercurrents in the Arctic Ocean}

\subsubsection{Brine Ejection from Ice}

When seawater freezes, the salt in the ice crystalline lattice dissolves within liquid inclusions of brine. As this brine is progressively drained (brine rejection), the ice desalinates. Due to the brine ejection, the salinity and the density of the surface water under the ice increases. This decreases the freezing point of the sea water [63].

Winds (waves) do not mix the water under the ice, so the salt gradient has time to grow to the point that the saline water starts to descend by gravity. The freezing of surface water (at a temperature of $-1.9{ }^{\circ} \mathrm{C}$ ) over the Antarctic continental shelf produces brine with a salinity of $34.62 \%$. The high density $\left(1,027.89 \mathrm{~kg} / \mathrm{m}^{3}\right)$ causes brine to sink [64].

Winter surface salinities in the Central Greenland Sea $\left(73^{\circ} 30^{\prime} \mathrm{N}\right.$ to $76^{\circ} 30^{\prime} \mathrm{N}, 3^{\circ} \mathrm{E}$ to $\left.5^{\circ} \mathrm{E}\right)$ from 1960 to 1998 were between $34.6 \%$ and $34.9 \%$ [65], with respective densities being $1,027.89$ to $1,028.10 \mathrm{~kg} / \mathrm{m}^{3}$.

By the end of the winter the bulk salinity of the one-year ice (1 to $2 \mathrm{~m}$ thick) rarely exceeds 6\% [66]. In multi-year sea ice with a thickness of $3.3 \mathrm{~m}$, the salinity systematically increases with depth from $0 \%$ at the surface to about $4 \%$ at the base [67].

In the summer, the ice melts and the surface water become fresher. Depending on the duration of the ice-free season, the upper $10 \mathrm{~m}$ to $40 \mathrm{~m}$ in the Arctic Ocean becomes diluted by meltwater. The summertime salinity ranges in the Canadian Basin from 30\% to 32.5\% and in the Eurasian Basin from 32\%o to 34\%o [68]. According to the salinity and density, the Arctic Ocean water profile can be divided into different layers [69] (see Table 1). 
Table 1. Summertime layering of the Arctic Ocean according to the salinity and density [69]

\begin{tabular}{|c|c|c|c|}
\hline Water layer & Temperature $\left({ }^{\circ} \mathrm{C}\right)$ & Salinity $(\%)$ & Density $\left(\mathrm{kg} / \mathrm{m}^{3}\right)$ \\
\hline Surface layer & 2 & 32 & $1,025.57$ \\
\hline $40 \mathrm{~m}$ to $400 \mathrm{~m}$ & 0 & 32.5 to 34.5 & $1,026.57$ to $1,028.89$ \\
\hline $400 \mathrm{~m}$ to $700 \mathrm{~m}$ & 1 & 34.5 to 35.0 & $1,029.06$ to $1,031.34$ \\
\hline Intermediate layer & -0.5 to 0 & 34.87 to 34.92 & $1,032.75^{*}$ \\
\hline Canadian Basin, $2,000 \mathrm{~m}$ to $4,000 \mathrm{~m}$ & -0.55 to -0.5 & 34.9 to 34.96 & $1,037.41$ to $1,046.40$ \\
\hline Eurasian Basin, $2,000 \mathrm{~m}$ to $4,000 \mathrm{~m}$ & -0.97 to -0.5 & 34.92 to 34.945 & $1,037.47$ to $1,046.39$ \\
\hline
\end{tabular}

$* 1,000 \mathrm{~m}$, salinity $=34.87 \%, \mathrm{~T}=-0.5^{\circ} \mathrm{C}$

In winter, brine ejection develops a density gradient which decreases downward from the surface. In order to be able to descend by gravity alone at a depth of $1,000 \mathrm{~m}$, surface water with a salinity of $40.6 \%$ o $\left(\mathrm{T}=-2{ }^{\circ} \mathrm{C}\right)$ would be needed. Such a high salinity is not likely obtained by brine ejection. However, the thrust by the DSW can force intermediate water with a salinity of $34.87 \%$ to $34.92 \%$ to descend even somewhat deeper than $1,000 \mathrm{~m}$.

\subsubsection{Amount of DSW Formed Annually via Brine Ejection in the Arctic and Southern Oceans}

According to a long-term trend from 1979 to 2008, the average maximum and minimum areal extents of sea ice are, respectively, $15,600,000 \mathrm{~km}^{2}$ and $6,500,000 \mathrm{~km}^{2}$ in the Arctic Ocean and $18,800,000 \mathrm{~km}^{2}$ and $3,100,000 \mathrm{~km}^{2}$ in the Southern Ocean. Typical ice thickness is about $2 \mathrm{~m}$ in the Arctic Ocean and about $1 \mathrm{~m}$ in the Southern Ocean [70].

The formation of ice in the boreal and austral sea areas occurs mainly during the winter. The effective freezing time is taken 6 months. Brine ejection from multi-year ice is omitted in the calculations. The sea ice in the Arctic Ocean starts to increase in the second half of September [71]. The salinity of the surface water in the Chukchi Sea rises during the last few days at the end of September from $31 \%$ to $32 \%$ [72] (See Figure 9). The rapid increase of the salinity is likely due to several cycles of freezing in which waves and tides frequently break the formed ice which, however, is not melted.

Because the salinity in the Norwegian and Greenland Seas is higher during the summer, the average salinity of the Arctic Ocean surface water at the moment when the solid ice-cover is formed is assumed to be $32.5 \%$. The average salinity when the brine starts to descend due to its density is assumed to be $34.75 \%$ [65].

In the Southern Ocean the meltwater is mixed with the saltier water from the open sea areas by waves and by the Antarctic Coastal Current and the ACC. That is why salinity of the surface water before freezing is taken to be $33 \%$.

Water starts to descend in the Arctic Ocean when the salinity of the surface water due to the ejection of brine is increased from $32.5 \%$ to $34.75 \%$ o $(\mathrm{a}=34.75 \mathrm{~g} / \ell-32.5 \mathrm{~g} / \ell$ $=2.25 \mathrm{~g} / \ell)$. In the Southern Ocean, $\mathrm{a}=34.62 \mathrm{~g} / \ell-33.0 \mathrm{~g} / \ell$ $=1.62 \mathrm{~g} / \ell$. The calculation of the parameters of $\mathrm{c}$ and $\mathrm{d}$ in the Equation (1) are presented in the Table 2.

In the Arctic Ocean the amount of the DSW formed in 6 months is $2 \times 10^{14} \mathrm{~m}^{3} / 1.5725 \times 10^{7} \mathrm{~s}=1.27 \times 10^{7} \mathrm{~m}^{3} / \mathrm{s}=$ $12.7 \mathrm{~Sv}$. Outside the proper freezing time the flow is reduced $30 \%$, being then $8.9 \times 10^{6} \mathrm{~Sv}$. The annual amount of DSW is 21.6 Sv. In the Southern Ocean the annual flow of the DSW is $26 \mathrm{~Sv}$. 


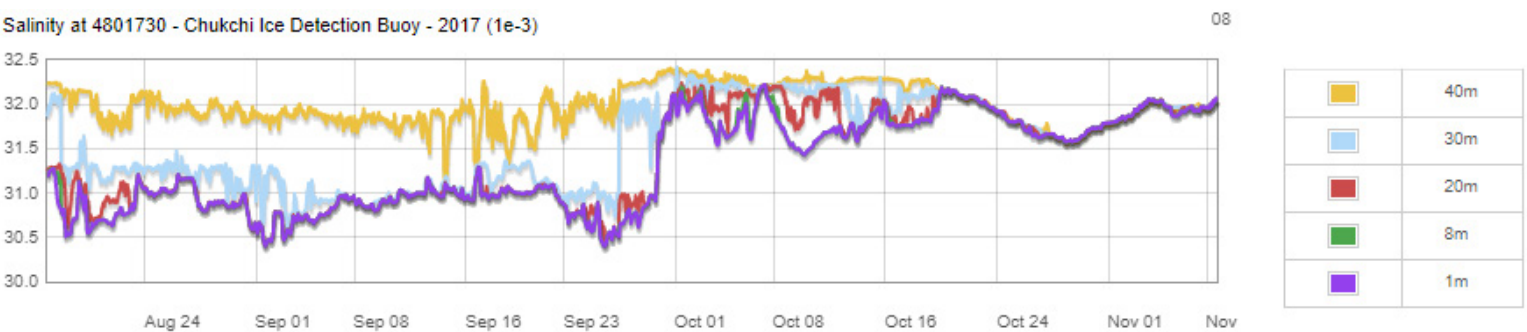

Figure 9. Development of the surface water salinity in the Chukchi Sea during autumn 2017 [72]

Table 2. Calculating the parameters of $\mathrm{c}$ and $\mathrm{d}$ in the proportion (1)

\begin{tabular}{|c|c|c|}
\hline & Arctic Ocean & Southern Ocean \\
\hline $\begin{array}{c}\text { Volume of the annually } \\
\text { forming ice }\left(\mathrm{m}^{3}\right)\end{array}$ & $1.82 \times 10^{13}$ & $1.82 \times 10^{13} \mathrm{~m}^{3}$ \\
\hline Mass of the ice $(\mathrm{t})$ & $1.66 \times 10^{13} \mathrm{t}$ & $1.43 \times 10^{13}$ \\
\hline $\begin{array}{c}\text { Ejected salt }(\%) \\
\mathrm{c}=\text { amount of annually } \\
\text { ejected salt }(\mathrm{t})\end{array}$ & 26.5 & 27 \\
\hline $\mathrm{a}=$ increment $(\mathrm{t})$ & $2.4 \times 10^{11}$ & $3.9 \times 10^{11}$ \\
\hline $\mathrm{b}\left(\mathrm{m}^{3}\right)$ & $1 \times 10^{-3}$ & $1.62 \times 10^{-6}$ \\
\hline $\mathrm{d}\left(\mathrm{m}^{3}\right)$ & $2.0 \times 10^{14}$ & $1 \times 10^{-3}$ \\
\hline
\end{tabular}

\subsubsection{The Thrust/Suction Created by the DSW in the} Arctic/Southern Oceans

The mass of the DSW (in one second) is $21.6 \times 10^{9} \mathrm{~kg}$. In the Arctic Ocean it would create a downward pressure of $2.16 \times 10^{10} \mathrm{~kg} / 1.56 \times 10^{14} \mathrm{~m}^{2}=1.46 \times 10^{-4} \mathrm{~kg} / \mathrm{m}^{2}$, which is $1.46 \times 10^{-8}$ technical atmospheres (at) a second. The annual pressure would be $3.1536 \times 10^{7} \mathrm{~s} \times 1.38 \times 10^{-8}$ at $/ \mathrm{s}=0.44$ at. This equals $44,000 \mathrm{~N} / \mathrm{m}^{2}$ [15]. This would be the annual thrust for the outflowing undercurrents and the suction for the inflow of the Gulf Stream currents in the Arctic Ocean.

In the Southern Ocean the respective values would be as follows: downward pressure is $1.39 \times 10^{-8} \mathrm{at} / \mathrm{s}$ and the annual pressure would be 0.44 at. This equals $44,000 \mathrm{~N} / \mathrm{m}^{2}$.

\subsection{Outflow of Undercurrents from the Arctic Ocean}

\subsubsection{Upwelling in Svalbard as Indicator of Undercurrent from the East Siberian Shelf}

It is understood that when great quantities of the DSW is formed at high latitudes there must elsewhere be an offset in which equal quantities of water is upwelling. Based on evidence provided by the models, it is suggested that the place would be either in the North Pacific Ocean or somewhere north of the Southern Ocean [2]. To support this theory there is provided no plausible mechanism for the upwelling and how the NEC and SEC could receive the compensation water for the continuous flow. This is unsurprising, as water molecules cannot, on annual basis, sink and rise several kilometers in the ocean (see Section 3.1.2).

The Ekman transport is suggested to be the cause for the occurrence of the real upwellings along the coasts of northwest Africa, southeast Brazil and southern Africa.
The northern coast of Svalbard is also an important upwelling area [73]. The cold DSW undercurrents are not at all associated with these upwellings [74].

The pressure created by winds tends to accumulate when they are able to blow constantly in the same direction over a wide distance. The length of the NEC is $4,500 \mathrm{~km}$. Its flow starts to increase in the middle of the North Atlantic Ocean (see Figure 4). The weekly average wind stress by the northeasterly trade winds near the coast of northwest Africa (at the starting point of NEC) is $0.20 \mathrm{~N} / \mathrm{m}^{2}$ [76].

Along the coast of Svalbard, the monthly average wind stress is $0.03 \mathrm{~N} / \mathrm{m}^{2}$. The wind direction, however, will vary from month to month [77]. During winter, the open sea area west and east from the Svalbard is restricted to a few hundred kilometers. It is likely that in the Svalbard, winds associated with the Ekman transport would be too weak to cause upwellings.

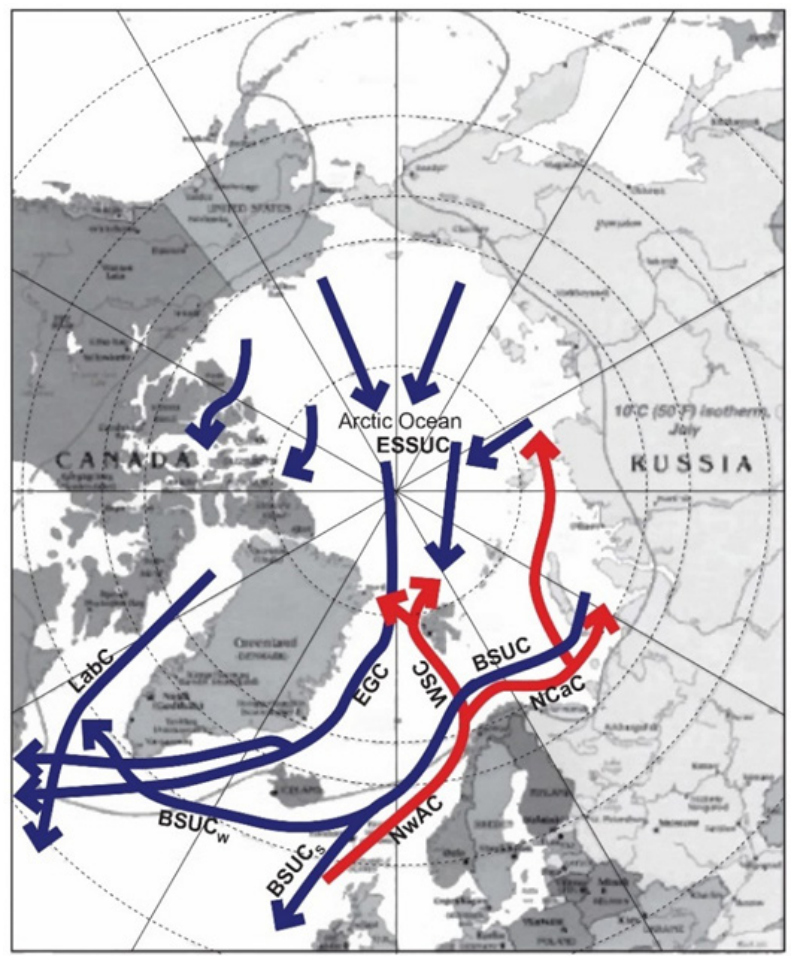

Figure 10. Undercurrents (blue) and GSC in the Arctic Ocean drawn on the map from [75]

The North Atlantic water brought by the WSC to Svarbald is originally infertile tropical water. However, a distinct feature of the upwelled waters in Svarbald have a 
high nutritional value. It is plausible that this kind of water is formed by the DSW, which is traveled along the bottom of the coastal seas in the East Siberian shelf [78]. After that, this DSW flows as an undercurrent below the multi-year ice cover, over the North Pole towards Svalbard. This undercurrent can be called the East Siberian Shelf Undercurrent (ESSUC) (see Figure 10).

\subsubsection{Undercurrents through the Fram and Denmark Straits}

Via two relatively deep canyons, the St. Anna Trough and the Voronin Trough, the DSW formed in the Kara Sea is conveyed to the Nansen Basin. The DSW from the Laptev Sea likely enters there as well. This DSW forms the ESSUC, which continues as the EGC. After the Fram Strait between Greenland and Svalbard, the EGC starts to bifurcate north of the Bosseville basin $\left(69^{\circ} \mathrm{N}, 20^{\circ} \mathrm{W}\right)$ in front of the Denmark Strait into the sEGC and the proper EGC.

The North Icelandic Jet (NIJ) was first measured in 2001 and 2002. It is a deep-reaching $(600 \mathrm{~m})$ and narrow (15 to $20 \mathrm{~km}$ ) barotropic jet with measured speeds exceeding 40 $\mathrm{cm} / \mathrm{s}$. Its flow volume is more than $1 \mathrm{~Sv}$. It is clearly not a part of the EGC, and it flows on the continental slope of Iceland [79]. The NIJ contains dense water [80].

Ice is a relatively good insulator [81]. Under the multi-year ice layer in the Arctic Ocean basin areas, the salinity of the surface water does not vary significantly. These areas are minor contributors of the DSW. Brine ejection produces high salinity water. It is likely that the NIJ contains this kind of water.

The NIJ joins south of the Bosseville basin $\left(67.5^{\circ} \mathrm{N}\right.$, $24^{\circ} \mathrm{W}$ ) from east-northeast to the proper EGC. Due to the flow direction of the NIJ, some of its water is diverted from the Greenland Shelf Break towards the north as well. This flow likely causes the bifurcation of the EGC. After bifurcation, both the EGC and sEGC transport dense intermediate and light surface waters [82]. After the Denmark Strait, the DSW is called the Denmark Strait Overflow Water, which then flows to the Labrador Sea.

\subsubsection{Undercurrents in and out the Norwegian Sea}

Due to the bottom topography of the Barents Sea, the flow of the DSW there to the Norwegian Sea is largely restricted to the Bear Island Channel between Svalbard and Norway [83]. This undercurrent can be called the Barents Sea Undercurrent (BSUC). In the Norwegian Sea, the DSW brought by the BUSC is called the Norwegian Sea Deep Water. It is likely that NIJ is a branch of the BSUC.

Observations of tritium concentrations in the overflow from the Arctic Ocean have shown that the source of the overflow to the Norwegian Sea is not the Arctic bottom water but that from depths close to $1,000 \mathrm{~m}$ [84].

Due to the bottom topography of the southern Norwegian Sea, the route of the BSUC towards the Iceland Basin is not straightforward. The Iceland-Faroe-Scotland
Ridge (IFSR) forms a continuous barrier over which both cold and warm water exchange between the proper North Atlantic Ocean and the southern Norwegian Sea is confined to the upper ocean $(\leq 850 \mathrm{~m})$. Poleward along the IFSR, above the sill, the Norwegian Sea is filled with cold, recently ventilated waters. To the south of the sill, the North Atlantic (Iceland Basin) is filled with warmer and saltier water at the same depths. It is presumed that these physical differences in the water would also be a sill-like barrier for the DSW flow towards the south [85]. Subsequently, the L-shape Faroe-Shetland Channel (see Figure 7) is expected to direct the flow of the dense water west over the sill in the IFSR into the Iceland Basin, where it is known as ISOW.

However, above depths of $850 \mathrm{~m}$ the density of stagnant water can hardly be a watertight obstacle for less dense flowing water. In the southern end of the L-shaped Faroe-Shetland Channel is the Wyville Thomson Ridge (WTR), above which percolation of some dense water to the Iceland Basin is also expected [85]. It is the only part of the outflow from the Norwegian Sea, the direction of which designates entering the Iceland Basin directly from the north.

It is obvious that in the southern Norwegian Sea the BSUC branches into western $\left(\mathrm{BSUC}_{\mathrm{W}}\right)$ and southern $\left(B_{S U C}\right.$ ) flows (see Figures 7 and 10). Just after the WTR starts the Rockall Channel, which at the southern end opens into the Porcupine abyssal plain in the West European Basin. In the Rockall Channel, a fresher, cold southward bottom flow has been observed, which may be the reason for the pervasive eddies in the eastern branch of the NAC flowing above it [51]. This is a likely route of the $\mathrm{BSUC}_{\mathrm{S}}$ into the West European Basin.

It has been shown that the ISOW spreads southward along the eastern flank of the Mid-Atlantic Ridge into the West European Basin as well [86-88].

The $\mathrm{BSUC}_{\mathrm{W}}$ flows through the RR via the Charlie Gibbs Fracture Zone and a small volume also comes via the Bight Fracture Zone into the Irminger Sea (a sea basin between Greenland and the RR). Southeast from Cape Farwell the $\mathrm{BSUC}_{\mathrm{W}}$ confluences with the $\operatorname{IrmC}_{\mathrm{W}}$.

\subsubsection{The Currents in and into the Labrador Sea}

The Baffin Bay and Labrador Sea are connected to the Canada Basin via narrow and shallow passages (the Amundsen Gulf and M'Clure Strait) and to the central Arctic Ocean area via Nares Strait [89]. Due to the shallowness of the passages the inflow is relatively small. According to the 5-year observations [90] the transport through the Lancaster Sound varies between 0 and $1.5 \mathrm{~Sv}$ (the Beaufort Sea inflow, see Figure 5). Three-year observations at four locations provide an estimated mean volume flux of $0.57 \pm 0.09 \mathrm{~Sv}$ from the Arctic Ocean into Baffin Bay via the Nares Strait [75]. There the current is called the Baffin Island Current (BIC).

At the Davis Strait the BIC yields an average flow of 2.7 
Sv [91]. After the Davis Strait, the flow in the west side of the Labrador Sea is called the Labrador Current (LabC). The Hudson Bay outflow to the LabC is $1 \mathrm{~Sv}$ to $1.2 \mathrm{~Sv}$ [92]. The LabC, BIC and the Hudson Bay outflow are cold ($\left.1.5^{\circ} \mathrm{C}\right)$ currents.

The LabC extends over the full water depth down to around 2,500 $\mathrm{m}$ [93]. However, it is estimated that $85 \%$ of the flow of the LabC is concentrated in a $50 \mathrm{~km}$ wide jet between $400 \mathrm{~m}$ and $1200 \mathrm{~m}$. The minimum of the seasonal variation in the upper-level circulation ( $400 \mathrm{~m}$ and up) but not deeper $(1000 \mathrm{~m})$ levels are in March and April while the maxima are in October [91].

At Hamilton Bank on the Labrador Shelf, the LabC appears as two streams or branches, with a small inshore stream carrying $15 \%$ of the transport and the main stream over the upper continental slope carrying roughly $85 \%$ of the $4 \mathrm{~Sv}$ relative to $1,500 \mathrm{db}$.

From the Hamilton Bank across the Labrador Sea the sea level is higher in the summer than in the winter throughout the year. This would indicate seasonal fluctuation in the flow of the LabC (maximum in summer and minimum in winter). In summer the difference in the sea level between the shelf and open sea is $0.09 \mathrm{~m}$ (see Figure 11) [91]. This would also indicate that downstream from the Hamilton Bank the flow over the shelf would encounter resistance, but in the open sea there would be no such resistance.

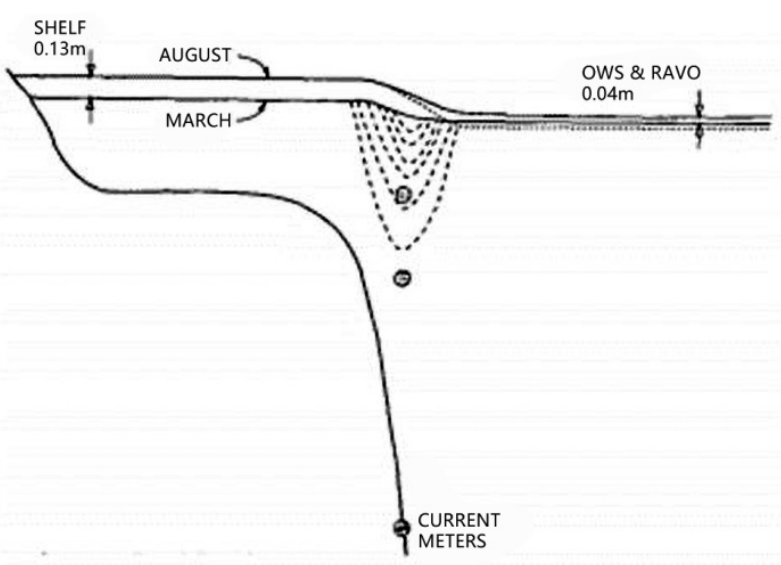

Figure 11. The annual and local variations in sea level northeast over the Hamilton Bank in the open Labrador Sea. (OWS Bravo = Ocean Weather Ship Bravo). The sea level is higher in the summer than in the winter. Throughout the year, the sea level is higher over the shelf than in the open sea [91]

Downstream of the Hamilton Bank is the Great Newfoundland Bank (GBN). A phytoplankton bloom is known to occur on the northern edge of the GBN [94]. This is likely due to the upwelling of the EGC and sEGC waters. An upwelling is impeding the flow of the LabC upstream from GBN and raising the sea level at the Hamilton Bank but not in the open sea.

The main part of the deep core EGC and sEGC water is diverted southeast by the GBN. Some of that water as well as some of the water of the $\mathrm{LabC}$ is also pushed south through the Flemish Cap in the GBN. This flow on the eastern slope of the GBN is traditionally named as the offshore branch of the LabC, having an average flow of 4.1 Sv relative to $100 \mathrm{dbar}$ [95]. Here it is called the $\mathrm{LabC}_{\mathrm{S}}$. If there would be interest to highlight the connection between the Mid-Atlantic Bight and the East Siberian Shelf, it could also be labeled as a continuation of the EGC.

In the Irminger Sea, the EGC, sEGC and $\mathrm{IrmC}_{\mathrm{W}}$ are flowing concurrently many hundred kilometers without interacting with each other. It is unlikely that mere ending of the Greenland coast at the level of Cape Farwell would cause them to start interacting.

A likely mechanism for the formation of the WGC is the confluence of the $\operatorname{IrmC}_{\mathrm{W}}$ with $\mathrm{BSUC}_{\mathrm{W}}$, which is approaching from east. It is likely that the EGC and sEGC do not participate in the confluence. Salt fingers caused by this confluence are discernable at Cape Farwell $\left(44^{\circ} \mathrm{W}\right)$ [96]. However, they are relatively small compared to the salt fingers in the $\mathrm{BraC} / \mathrm{MalC}$ and $\mathrm{AguC} / \mathrm{BenC}$ confluences. One important reason for this may be that the volume transport of the $\mathrm{IrmC}_{\mathrm{W}}$ is much smaller than that of the $\mathrm{BraC}$ and AguC. In spite of that, it is possible that the 'epicenter' of the confluence would be further east of Cape Farewell over the Greenland continental shelf.

Two retroflected surface currents are formed in the confluence. Both of them contain $\mathrm{BSUC}_{\mathrm{W}}$ and $\mathrm{IrmC}_{\mathrm{w}}$ water. One of the retroflected currents veers off the Greenland coast into the Labrador Sea. Its warmth is rapidly dissipated and the flow direction turned southeast by the LabC. The other is the WSC flowing along the coast as a warm current (relative to the ambient cold waters).

The $\mathrm{LabC}_{\mathrm{S}}$ creates fog during its route south and upwells in Massachusetts Bay [97]. $\mathrm{LabC}_{\mathrm{S}}$ is traceable up to the Mid-Atlantic Bight in front of New York [98]. The cold $\mathrm{LabC}_{\mathrm{S}}$ prevents the warming influence of the Gulf Stream from affecting the northeastern coasts of Canada and USA.

From the GBN southeast, the current flowing southeast in the North Atlantic Ocean can be called the North Atlantic Undercurrent (NAUC).

\subsubsection{The Upwelling of the NAUC Waters}

The GBN is steering the direction of the outflow of the NAUC from the Labrador Sea towards the coast of the northwest Africa. Factors that force the outflow to maintain this direction are the upwellings in the coast of Morocco and the suction caused by the NEC at its starting point between the latitudes of $10^{\circ} \mathrm{N}$ and $20^{\circ} \mathrm{N}$.

The flow of the NAUC follows Bernoulli's law, which states that water molecules moving along streamlines trade speed for height or for pressure. This implies that the flow of the NAUC would be slowing, covering a wider area and getting thinner. At around $52^{\circ} \mathrm{N}, 13^{\circ} \mathrm{W}$ to $22^{\circ} \mathrm{W}$, the flow bed of the NAUC is widened as the $\mathrm{BSUC}_{\mathrm{S}}$ joins it.

The upwellings of the NAUC is called the coastal upwelling ecosystem of the CanC, which in its broadest sense covers a 3,500 km of coastal area from Dakar (NW 
Africa) to A Coruña (NW Spain) $\left(10^{\circ} \mathrm{N}\right.$ to $\left.43^{\circ} \mathrm{N}\right)$. Coastal upwellings in Iberia [99] are likely caused by the NAUC water via the $\mathrm{BSUC}_{\mathrm{S}}$. The northern and southern limits of the upwelling shift seasonally [100-102]. The upwellings are important in keeping the NAUC route passable for continuous flow.

The CanC upwelling region off the coast of northwest Africa can be divided into three subregions: the weak permanent, permanent, and seasonal upwelling zones [103]. The seasonal upwelling zone is between Cape Blanc and the Canary Islands (from $13^{\circ} \mathrm{N}$ to $20^{\circ} \mathrm{N}$ ). The permanent upwelling zone is between $20^{\circ} \mathrm{N}$ and $26^{\circ} \mathrm{N}$, and the weak permanent upwelling zone between $26^{\circ} \mathrm{N}$ and $33^{\circ} \mathrm{N}$.

A wide upwelling area supports the hypothesis that the NAUC arrives as a wide and slow flow across the North Atlantic Ocean. Seasonal changes connect the NAUC water to the seasonal changes in the formation of the DSW in the Arctic Ocean.

\subsubsection{The Canary Current}

The CanC forms mainly from the upwelled waters of the NAUC on the northwest African coast. It receives water from the Azores and Portugal currents as well. The CanC detaches from the coast and merges into the NEC. CanC is rather broad (approximately $1,000 \mathrm{~km}$ ), relatively slow (approximately $10 \mathrm{~cm} / \mathrm{s}$ to $30 \mathrm{~cm} / \mathrm{s}$ ), equatorward flow extending from the surface to an average depth of approximately $500 \mathrm{~m} \mathrm{[104].}$

The portion of the CanC which lies off the Iberian west coast is primarily called the Portugal Current [105]. The Polar Undercurrent (PUC), which flows north along the northwest African coast, is a countercurrent of the CanC. It also contains the upwelling waters of the NAUC diverted north from the African coast. PUC is likely causing the upwellings in Cadiz Bay [106]. A detailed description of the multitude of currents along the coast of northwest Africa is described in [78].

The CanC flow has the maximum intensity from July to November (see Figure 12). The LabC flow has its maximum in August and minimum in March. These fluctuations demonstrate a connection via NAUC.

The distance from the GBN to the Mauritanian coast is $4,600 \mathrm{~km}$. Then the traveling time of the NAUC would be $\mathrm{n}$ +1 years, where $n$ may be $1,2,3$ or 4 . If the time is one year, the flow speed would be $14 \mathrm{~cm} / \mathrm{s}$. This is more or less a suitable speed range for an undercurrent jet. A traveling time of 2 to 4 years would give an average flow speed of 7.3 to $3.6 \mathrm{~cm} / \mathrm{s}$ respectively. This may be a more appropriate average range for the flow speed of NAUC.

The CanC is cool current because the upwelling waters of the NAUC are cold. Cool water desiccates the winds from the sea, which is the main cause for the aridity of the Sahara Desert.

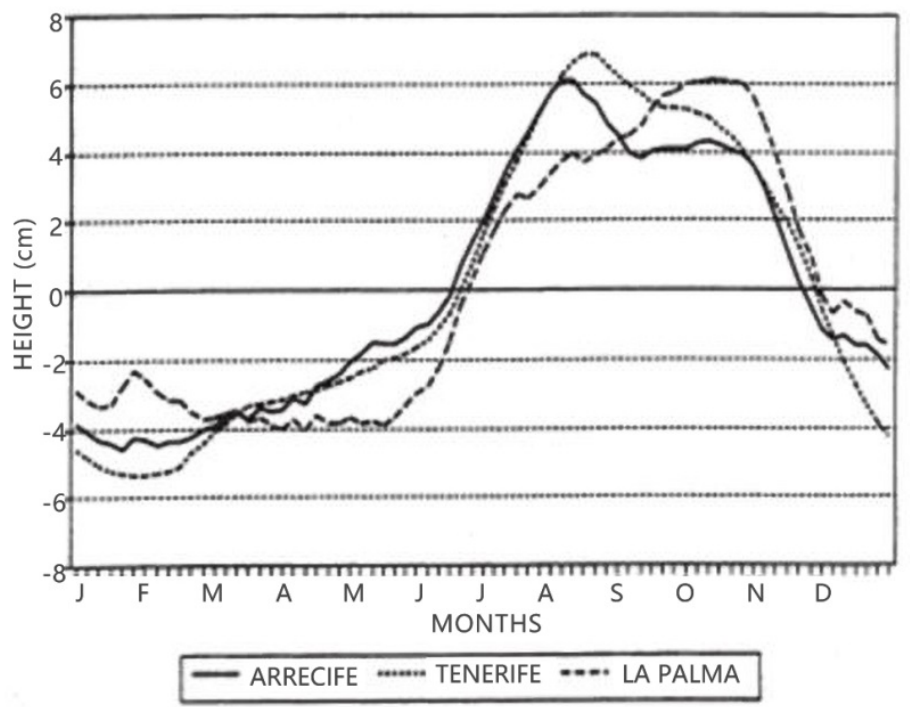

Figure 12. The seasonal variation of the Canary Current at Arrecife, Tenerife and La Palma stations, 1960 to 1972. [107]. 


\subsubsection{The Salinities of the North Atlantic and North Pacific Oceans}

It has been established that the North Pacific Ocean is considerably fresher than the North Atlantic Ocean (see Figure 13). Considering that the throughflow in the Bering Strait is primarily driven from the Arctic to the Pacific Ocean [62], it is logical to suppose that due to the shallowness of the Bering Strait, only melting water/lowest density DSW driven mainly by the $\mathrm{NCaC}$ can go through it. The saltier deep-water remains in the Arctic Ocean and from there spreads into the proper North Atlantic Ocean driven by, the NEC, GSC and NAUC, making it saltier over time.

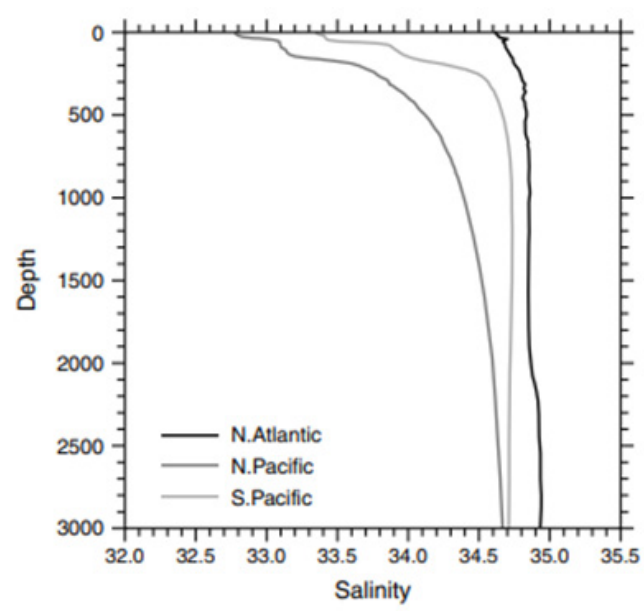

Figure 13. Subpolar salinity distribution of the Atlantic and Pacific oceans at depths down to $3000 \mathrm{~m}$. The Northern Hemisphere profiles are from about $50^{\circ} \mathrm{N}$. The Southern Hemisphere profile is from the Pacific Ocean at about $65^{\circ} \mathrm{S}[20]$.

\subsection{South Atlantic Circulation}

\subsubsection{Brazil and Malvinas Currents}

The geostrophic transport of the MalC relative to the $1400 \mathrm{~m}$ level (or sea floor, if shallower) across $46^{\circ} \mathrm{S}$, is 10 $\mathrm{Sv}$. The $\mathrm{BraC}$ geostrophic volume transport relative to $1400 \mathrm{~m}$ across $19^{\circ} \mathrm{S}$ to $24^{\circ} \mathrm{S}$ is $7 \mathrm{~Sv}$, and across $38^{\circ} \mathrm{S}$ is 19 Sv. This represents an increase of approximately $63 \%$ [108].

On the coast along the route of the $\mathrm{BraC}$ there are two distinct upwelling zones: the first around $13^{\circ} \mathrm{S}$ [109], and the second, more intense one in the Cabo Frio region $\left(23^{\circ} \mathrm{S}\right.$, $42^{\circ} \mathrm{W}$ to $45^{\circ} \mathrm{W}$ ) [110]. Water from the upwelling in the Capo Frio region is a likely reason for the increased flow.

The MalC is likely formed when the Antarctic Coastal Current is partially diverted north by the Antarctic Peninsula (see section 3.7.2). It flows northward along the continental slope of Argentina in a band that is $100 \mathrm{~km}$ wide until it reaches the $\mathrm{BraC}$.

\subsubsection{Upwellings of the MalC in the Brazilian Coast at} $23^{\circ} \mathrm{S}$ and $13^{\circ} \mathrm{S}$
Northeasterly winds are suggested to cause the upwellings in the Capo Frio region. If those winds really were able to affect the bottom water in the waterfront and create upwellings, they should be able to create a substantial surface flow as well. However, there are no indications of a northeast surface current starting offshore the Capo Frio region and continuing into the South Atlantic Ocean. Again, winds associated with the Ekman transport are too weak to generate major upwellings.

The nutrient concentration, primary biomass and productivity as well as fishery production is lower in the Capo Frio region upwelling waters than in the other main upwelling regions elsewhere [110]. This would be plausible evidence that substantial amounts of the $\mathrm{BraC}$ tropical and infertile water mixes with the deep-core of the $\mathrm{MalC}$ in the confluence (see section 3.1.4).

The biological productivity in the upwelling area in front of Baía de Todos os Santos $\left(13^{\circ} \mathrm{S}\right)$ is even lower [109]. After upwelling in the Capo Frio, the volume transport of the MalC is reduced, which further lowers the nutritional value of the upwelled water at $13^{\circ} \mathrm{S}$. Subsequently, the MalC can be traced as the source of the $13^{\circ} \mathrm{S}$ and $23^{\circ} \mathrm{S}$ upwellings.

The vegetation of the Capo Frio region is semiarid in contrast with that of other parts of the Brazilian coast [110]. Desiccation of the continental climate is typical oceanic-atmospheric physical process at the upwelling site of a cold current. In the absence of the confluence with the $\mathrm{BraC}$, the upwellings due to the MalC could make the Capo Frio region a desert.

\subsubsection{South Atlantic, Agulhas and Benguela Currents}

At the beginning in the Argentine Basin the volume transport of the SAC is $30 \mathrm{~Sv}$ to $37 \mathrm{~Sv}$, relative to the $800 \mathrm{~m}$ to $1000 \mathrm{~m}$ depth [111]. In the vicinity of southern Africa, the volume transport is reduced to $17 \mathrm{~Sv}$. Surface velocities of the SAC in the Argentine Basin are of the order of 20 $\mathrm{cm} / \mathrm{s}$ to $27 \mathrm{~cm} / \mathrm{s}$, but in the Cape Basin near South Africa they are decreased by half [112]. It is obvious that the main driving force for the $\mathrm{SAC}$ is the original momentum which it acquires during the confluence of the $\mathrm{BraC} / \mathrm{MalC}$. The westerlies at the $38^{\circ} \mathrm{S}$ to $40^{\circ} \mathrm{S}$ level are only an auxiliary driving force.

The Agulhas Current (AguC) transports warm water from the Indian Ocean along the southeast coast of South Africa. It starts approximately at the border between Mozambique and South Africa and stretches along the eastern seaboard of South Africa, down to the latitude of Port Elizabeth. Farther downstream it flows past the broad continental slope and over the Agulhas Bank [113]. The volume transport of the AguC is $65 \mathrm{~Sv}$ to $85 \mathrm{~Sv}$ [112].

The retroflection of the AguC starts just south of $37^{\circ} \mathrm{S}$ [113] and is completed at $40^{\circ} \mathrm{S}, 18^{\circ} \mathrm{E}$ (see Figure 14) [114]. Much of the AguC water is then diverted east and recirculates in the southwest Indian Ocean sub-gyre as 
South Indian Ocean Current (SIOC). About $10 \mathrm{~Sv}$ of the AguC flow is diverted northeast into the South Atlantic [115] as the Agulhas eddies. They are among the most energetic in the world and should have lifetimes of 5 to 10 years [112]. These eddies are likely formed between $37^{\circ} \mathrm{S}$ to $38^{\circ} \mathrm{S}$ (see Section 3.6.4). SAC flows between $38^{\circ} \mathrm{S}$ to $40^{\circ} \mathrm{S}$, so its water is not diverted by the Agulhas eddies, neither are there other plausible driving forces which could divert the SAC to flow north or northeast. Subsequently, the $\mathrm{SAC}$ is not the origin of the BenC but south of $38^{\circ} \mathrm{S}$ it is participating to the retroflection of the AguC.

The flow of the AguC is 4 to 5.5 times greater than that of the SAC. If only these two currents would participate in the retroflection, the southwest-bound momentum of the $\mathrm{AguC}$ water molecules would overpower the eastbound momentum vector of the SAC water molecules. It would be expected to form a relatively warm surface current of $\mathrm{AguC}+\mathrm{SAC}$, the momentum of which would be directed south or south-southwest.
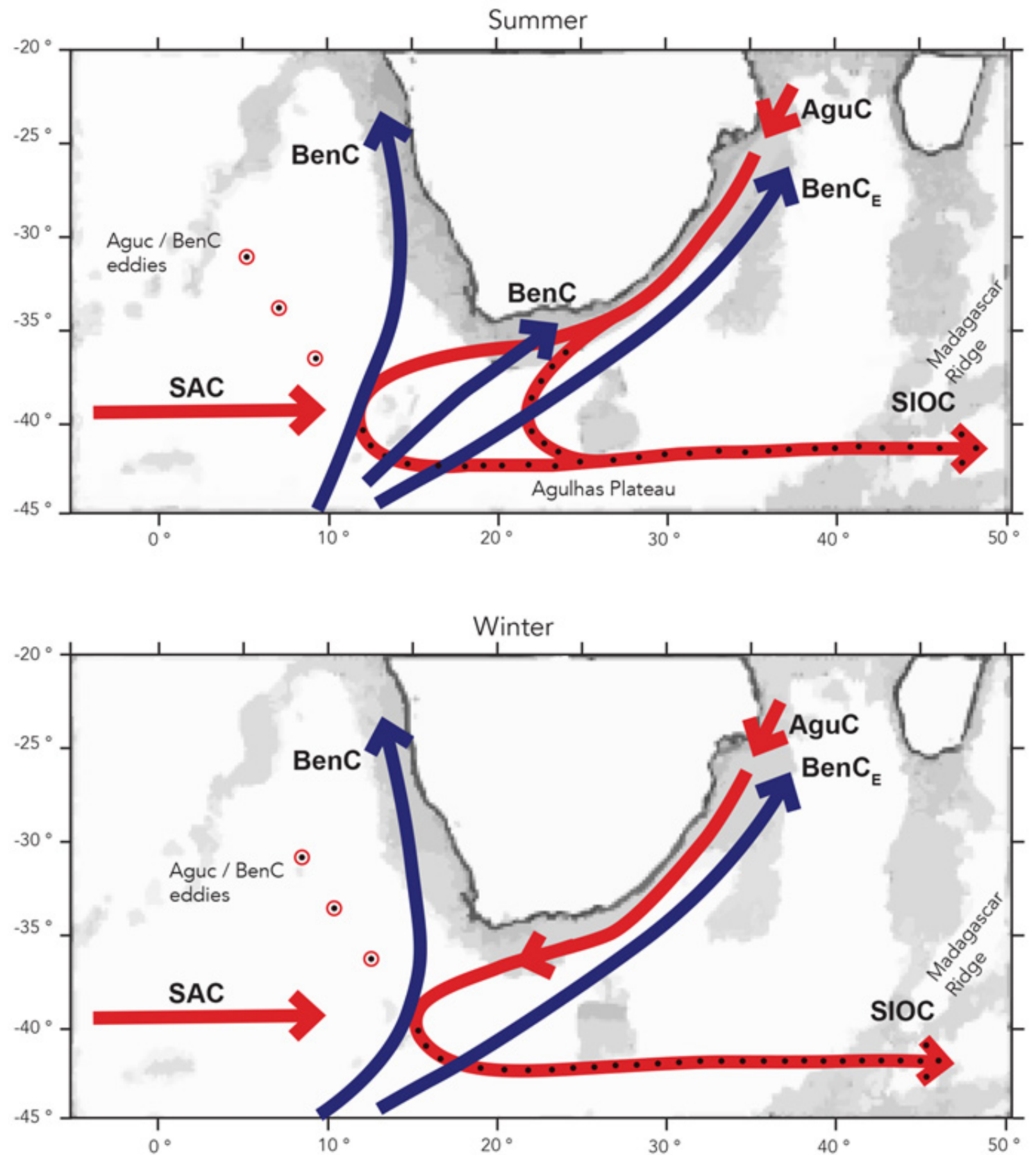

Figure 14. Seasonal differences in the circulation pattern of the AguC and BenC during austral winter (below) and summer (above). Currents are drawn on the map from [117] 
However, the momentum of the SAC water molecules overpowers that of the AguC molecules, and the AguC water molecules are retroflected east. This is possible only when the horizontal movement of the AguC water molecules cease moving or at least move very slowly. In the middle of the ocean the only possible mechanism to do that would be the DDC with large $\Delta \mathrm{T}$ - the confluence between warm and cold current.

The only plausible candidate as the cold current for the confluence is the Benguela Current (BenC), which is a branch of the ACC [116].

It is plausible to presume that the BenC approaches the tip of South Africa from the southwest as a wide flow, even though there seems to be no available data of the BenC flow route and its volume transport between the ACC and the Cape of Good Hope. The Agulhas Bank divides the deep-core of the BenC into two branches. One of the branches is the BenC flowing north along the west coast of South Africa. The second can be called the $\mathrm{BenC}_{\mathrm{E}}$, which flows north along the east coast of South Africa (see Figure 14).

This hypothesis is supported by the fact that the Agulhas Undercurrent (or the $\mathrm{BenC}_{\mathrm{E}}$ as it is here called) has been observed and measured near Port Edward $\left(31^{\circ} \mathrm{S}\right)$. The core of the undercurrent is centered around a depth of $1200 \mathrm{~m}$, against the continental slope and directly below the surface core of the south-westward flowing AguC. Maximum velocities of $30 \mathrm{~cm} \mathrm{~s}^{-1}$ to the northeast are observed in the undercurrent, and its volume transport is $6 \mathrm{~Sv}$, approximately one tenth that of the AguC [118].

\subsubsection{Confluence of the $\mathrm{BenC}$ and $\mathrm{AguC}$}

In front of the Agulhas Bank, at approximately $37^{\circ} \mathrm{S}$, $17^{\circ} \mathrm{E}$ to $39^{\circ} \mathrm{S}, 13^{\circ} \mathrm{E}$ (NW to SE), there is a salt finger which is $250 \mathrm{~km}$ wide on the surface, and $150 \mathrm{~km}$ at a depth of $1,000 \mathrm{~m}$ (see Figure 15). The salt finger observed at the location matches those in the $\mathrm{BraC}$ vs. MalC confluence.

The $\Delta \mathrm{T}$ is so great that a vigorous DDC results. In the salt finger the waters of the AguC and BenC mix. The warm ring-like Agulhas eddies drift northwest to the South Atlantic [113]. These eddies contain more of the AguC water than that of the BenC. They are likely to form between the $37^{\circ} \mathrm{S}$ to $38^{\circ} \mathrm{S}$. With these eddies the heat (or at least part of it) which the NBC transports into the North Atlantic Ocean is compensated by the heat from the Pacific and Indian Oceans.

The Agulhas Bank diverts that part of the deep core $\mathrm{BenC}$, the momentum of which is more or less untouched in the confluence, to flow north. The confluence of the $\mathrm{AguC}$ and $\mathrm{BenC}$ at the tip of Africa is shown in the eddy current chart as well (see Figure 4).

South of $38^{\circ} \mathrm{S}$, the horizontal movements of the AguC and BenC molecules start to slow down even at the surface, because the direction of the movements are almost opposite. Further south, the momentum of the BenC water molecules might overpower the momentum of the AguC water molecules. The SAC is then able to leach the still-standing/slow-moving surface water of the AguC and BenC with it. In the Indian Ocean this current is called the South Indian Ocean Current (SIOC).

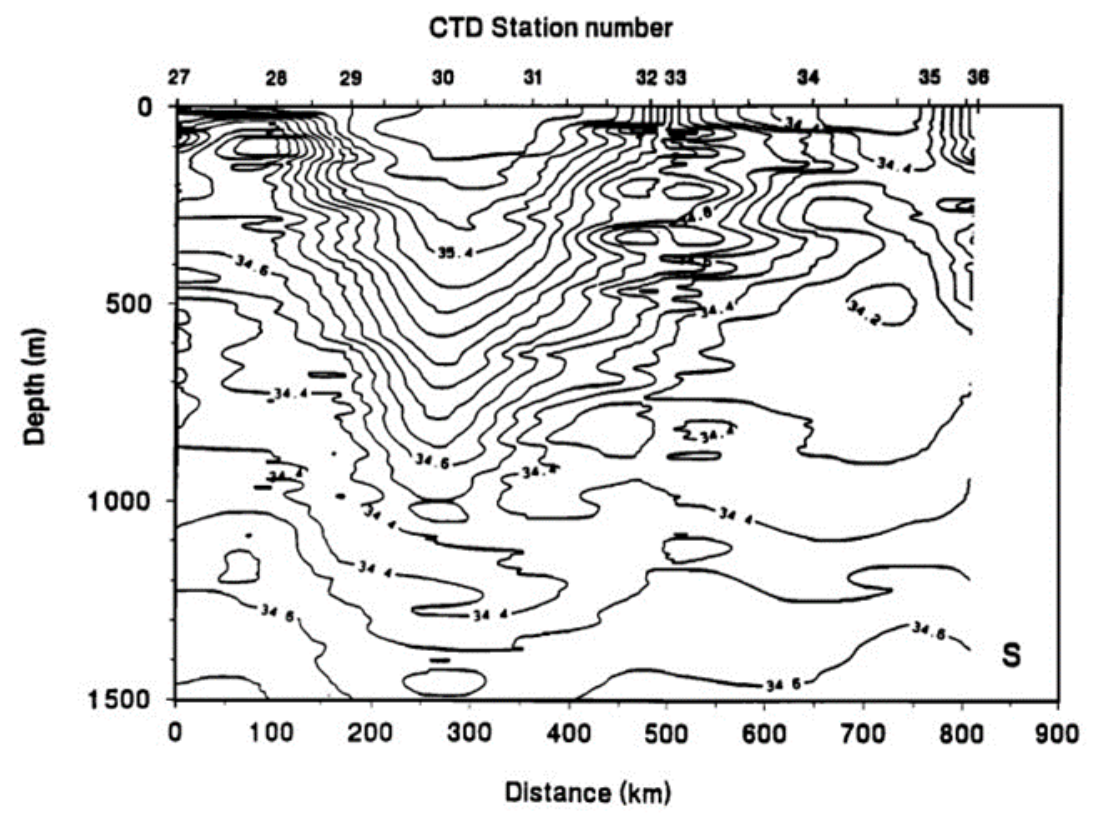

Figure 15. A major salt finger due to the vigorous DDC in the AguC vs. BenC confluence during a hydrographic cruise in the Agulhas retroflection region in February/March 1987. The section showed extends from $37^{\circ} \mathrm{S}, 17^{\circ} \mathrm{E}$ to $39^{\circ} \mathrm{S}, 13^{\circ} \mathrm{E}$ (in the direction $\mathrm{NW}$ to $\mathrm{SE}$ ) [113] 


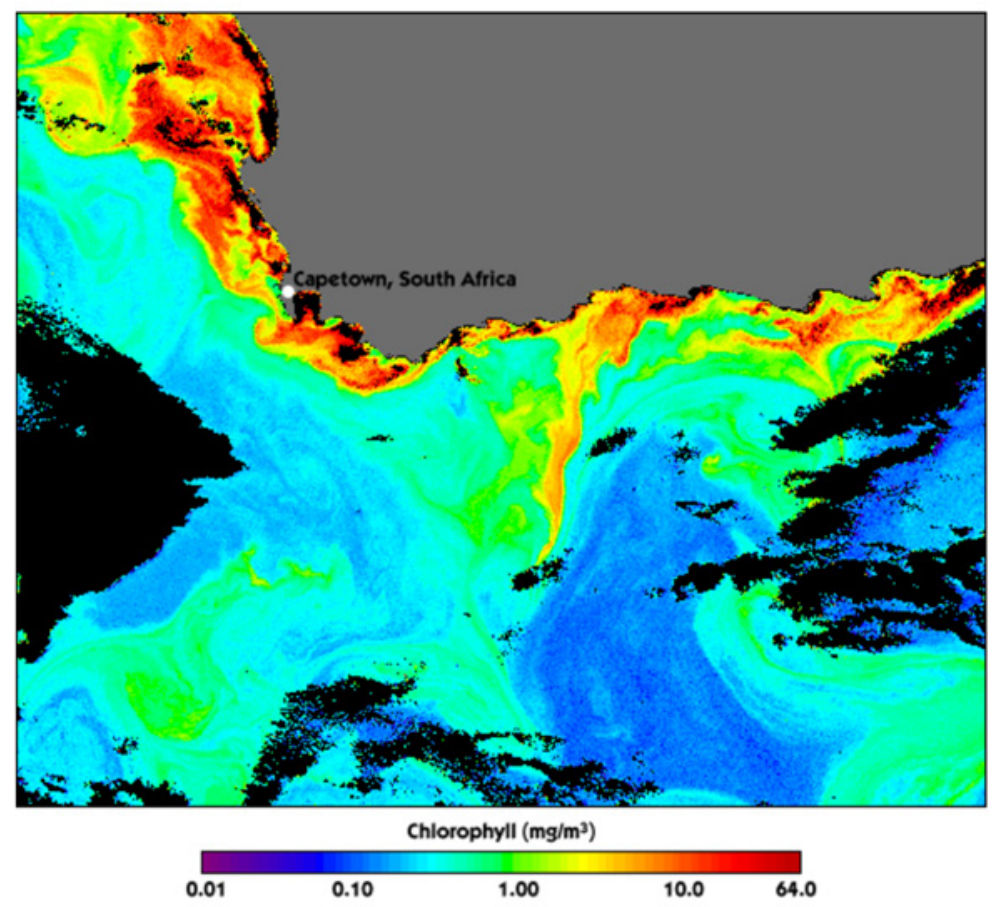

Figure 16. False color image. showing chlorophyll concentrations on the south and west coast of South Africa due to the BenC, March 28, 1999 [119]

During austral summer, the retroflection of the AguC occurs in two places, in front of the Agulhas Bank and in front of Port Elizabeth at $35^{\circ} \mathrm{S}, 25^{\circ} \mathrm{E}$ (see Figures 14 and 16) [117]. A plausible explanation for this is that in summer the flow of the BenC is so great that there is not enough AguC water to slow down all of the BenC water in the salt finger in front of the Agulhas Bank. Subsequently. some of the BenC continues to flow and the second confluence takes place in front of Port Elizabeth. The resulting retroflected $\mathrm{AguC} / \mathrm{BenC}$ current is seen protruding south in March in the middle of Figure 16 [119-120]. It is in this second confluence that the Natal eddies are likely formed.

\subsubsection{Upwellings Caused by the BenC and $\mathrm{BenC}_{\mathrm{E}}$}

The BenC creates a large upwelling ecosystem situated off the west coast of Angola, Namibia, and South Africa $\left(5^{\circ} \mathrm{S}\right.$ to $37^{\circ} \mathrm{S}, 0^{\circ}$ to $\left.26^{\circ} \mathrm{E}\right)$. At the center of the upwelling region is an area of year-round coastal upwelling at $15^{\circ} \mathrm{S}$ to $30^{\circ} \mathrm{S}$ and a region of seasonal upwelling at $30^{\circ} \mathrm{S}$ to $34^{\circ} \mathrm{S}$. In the region between approximately $15^{\circ} \mathrm{S}$ and $37^{\circ} \mathrm{S}$ there is a poleward undercurrent along the shelf slope and bottom [121].

It has been found that the mean meridional transport of the BenC in the upper $800 \mathrm{~m}$ decreases from $23 \pm 3 \mathrm{~Sv}$ at $31^{\circ} \mathrm{S}$ to $11 \pm 3 \mathrm{~Sv}$ at $28^{\circ} \mathrm{S}$ [122]. This is in the area of year-round coastal upwelling. It implies that the upwellings along the Southwest African coast are due to the BenC. The Ekman transport does not necessarily have any important part in the upwellings.

Around $24^{\circ} \mathrm{S}$ to $30^{\circ} \mathrm{S}$, most of the BenC veers from the coast northwest and joins the SEC [123]. The warm tropical southward moving coastal Angola Current meets the Benguela Upwelling System at the Angola-Benguela Frontal Zone at approximately $15^{\circ} \mathrm{S}$ to $17^{\circ} \mathrm{S}$. [121] and separates the rest of the BenC from the coast.

During the austral summer, the BenC creates an upwelling ecosystem situated off the south coast of South Africa. Pigment indices indicate that in austral summer the phytoplankton biomass is high on the west coast of South Africa from Cape Columbine along the coast to the Cape Peninsula, but also quite extensive in the autumn [124]. In the images taken by NASA it can be seen that phytoplankton blooms on the southern coast of South Africa, in front of Port Elizabeth starting from November [119-120]. This implies that the retroflected current south of Port Elizabeth contains BenC water.

The $\mathrm{BenC}_{\mathrm{E}} /$ Agulhas Undercurrent likely causes the upwelling in the Gulf of Oman [125].

The blooming of the phytoplankton in the summer can take as further evidence that the BenC is connected to the formation of the DSW in the Southern Ocean. During austral summer, the formation of the DSW is low. The flow time of the BenC from the ACC to the tip of the Africa is likely $n+0.5$ years, $n$ being $1,2,3$, or 4 .

\subsection{Antarctic Circumpolar and Coastal Currents}

\subsubsection{The ACC and Its Flow in Three Well-Separated} Fronts

The westerlies are the driving force of the Antarctic Circumpolar Current (ACC). The ACC encircles Antarctica, extending from the surface to the bottom of the ocean. Due to the open ocean area around the world, the wind stress is able to accumulate to the maximum level 
obtainable physically in the Earth. That is why the ACC is the strongest of the ocean currents. Local instabilities in the wind stress and the bottom topography of the Southern Ocean cause the ACC flow to meander. It is not, therefore, a smooth, large-scale flow. Rather, most of its transport is concentrated in three, well-separated fronts [126-127].

Fronts are separate regions with distinct temperature and salinity signatures [126]. The Southern ACC Front is the southernmost, the Polar Front (PF) is in between and the Subantarctic Front (SAF) is the northernmost of these ACC cores [127]. The SAF is characterized by surface temperatures near $7{ }^{\circ} \mathrm{C}$ to $9{ }^{\circ} \mathrm{C}$ and a salinity minimum of $33.8 \%$ to $34.0 \%$ [ [128].

The PF zone is also called the Antarctic Convergence zone. It is located between approximately $50^{\circ} \mathrm{S}$ and $60^{\circ} \mathrm{S}$. On average, the Antarctic surface water becomes saltier and colder to the south of the PF [129]. Hydrographically, the $\mathrm{PF}$ is the northern boundary to cold $\left(-1.5^{\circ} \mathrm{C}\right.$ to $\left.2^{\circ} \mathrm{C}\right)$ near-surface water formed by winter cooling [112].

The baroclinic transport of the ACC above $3,000 \mathrm{~m}$ through Drake Passage is $107.3 \pm 10.4 \mathrm{~Sv}$ and has been steady between 1975 and 2000 . The baroclinic transport relative to the deepest common level is $136.7 \pm 7.8 \mathrm{~Sv}$. (Estimates of the volume transport of the sea currents vary, depending on the chosen reference depth level of the current). The ACC volume transport is mainly carried in two jets, the SAF, with $53 \pm 10 \mathrm{~Sv}$, and the PF, with $57.5 \pm$ 5.7 Sv. The Southern SCC Front transports $9.3 \pm 2.4 \mathrm{~Sv}$ [130].

\subsubsection{The Antarctic Coastal Current and Antarctic Intermediate Water}

The Antarctic Coastal Current ( $\mathrm{AnCoC}$ ), also known as the East Wind Drift Current, is the westward flow close to the Antarctic coastline. It is the counter-current of the ACC. The driving forces for the $\mathrm{AnCoC}$ are the shear of the ACC and the prevailing easterly winds found south of approximately $65^{\circ} \mathrm{S}$ [127]. Although $\mathrm{AnCoC}$ is circumpolar, the Antarctic Peninsula partially impedes its flow [131].

Impeded part is diverted to flow north and the unimpeded part flows west into the Drake Passage. There it meets the east-flowing ACC. During their encounter, the speed of the ACC flow is slowed while that of the AnCoC ends totally. This situation likely allows the north diverted part of the AnCoC water to penetrate deep into the ACC flow. This thrust would possibly divert some of the ACC flow north. It would then continue as the MalC. In the BraC vs. MalC confluence, the MalC water upwells, which keeps the route passable. The confluence can be taken as a mid-route suction-like driving force for the MalC.

The Antarctic Intermediate Water (AAIW) is found just north of the SAF [127]. It is characterized by a salinity minimum (core of AAIW) centered at depths of $600 \mathrm{~m}$ and $1,000 \mathrm{~m}[132]$.

During summer the ice melts in the Southern Ocean, and the surface water is freshened. The AnCoC spreads the meltwater so that it enters the influence of the deep-sea current pump areas, which are active throughout the year (as Newton's first law states). The low-salinity meltwater then enters the deep-sea currents. This causes the formation of the AAIW. At the moment, it protrudes over the equator up to $10^{\circ} \mathrm{N}[133]$.

\subsubsection{Outflow from the Southern Ocean}

In terms of the outflow of the DSW, the Arctic and Antarctic ocean areas show marked differences due to the bottom topography. In the Southern Ocean, the DSW has immediate, free access to the sea everywhere. It is piecemeal ending up to the ACC. The ACC and the AnCoC immediately provide the compensating surface water. Subsequently, unlike in the Arctic Ocean, in the Southern Ocean there is no possibility to develop a focusing suction to draw a narrow and strong compensating surface inflows.

However, entering the DSW in the ACC is a slow process, there is time for the thrust to develop. The overall flow of the DSW is $26 \mathrm{~Sv}$, which is generating an annual thrust of $44,000 \mathrm{~N} / \mathrm{m}^{2}$. Considering the eastern flow direction of the ACC, the thrust puts the DSW to move northeast, forming the BenC in the Southern/South Atlantic Ocean. The suction from the starting point of the SEC is determining the diversion place of the BenC from the ACC. Moreover, here the auxiliary mid-route suction-like driving force is the BenC vs. AguC confluence. Like the flow of the NAUC in the North Atlantic, the flow of the BenC in the Southern Ocean obeys Pascal's law and follows Bernoulli's equation. Its initial speed slows and the flow bed widens before it arrives to the tip of Africa where it is divided into northern $(\mathrm{BenC})$ and eastern $\left(\mathrm{BenC}_{\mathrm{E}}\right)$ undercurrents.

The undercurrent outflow from the Southern Ocean is so effective that the South Atlantic bottom water is clearly colder than that of the North Atlantic [133]. It is obvious that the DWBC would confront more repulsion than what the original thrust obtained by DSW in the Arctic Ocean would be. The outflowing undercurrents create a barrier for any incoming deep-sea current entering the ACC.

\subsection{Recommendations for the Future Studies}

The undercurrents in the Southern and Arctic oceans are not well known. A potential, though slow and expensive method to clarify their routes would be the use of tracer substances. In the Arctic Ocean the appropriate seeding places would be the Barents, Chukchi, Kara, Laptev and East Siberian seas. Ultimately, the findings would also provide information about the route of the NAUC in the Atlantic Ocean as well as about the travel time of water molecules from the East Siberian shelf to the Nortwest African coast.

In the Southern Ocean seeding of tracer substances on the eastern coast of the Antarctic Peninsula could be a 
means to clarify the importance of the $\mathrm{AnCoC}$ in the formation of the MalC. Seeding them in the ACC clearly east from the South Georgia and South Sandwich Islands would clarify the route of the BenC. It would also offer data on the BenC vs. AguC confluence, the travel time from the ACC to the tip of Africa, and even further as BenC and $\mathrm{BenC}_{\mathrm{E}}$.

In the Pacific Ocean, the warm Kuroshio and cold Oyashio currents meet off-shore of Japan. The mixed water zone between the currents[134] is likely a confluence zone. Salt fingers could be measured there. The confluence zone of the $\mathrm{IrmC}_{\mathrm{W}}$ vs. $\mathrm{BSUC}_{\mathrm{W}}$ could also be localized by measuring salt fingers southeast from Cape Farewell, over the Greenland continental shelf.

At present, the area of annually melting ice is annually measured in the Arctic Ocean. Yet to clarify possible long-term trends in fluctuations of the GSC, the volume of the annually forming ice should be measured as well. Once the volume is known, the amount of released salt can be estimated, as well as that of the DSW. Similar measurements could be carried in the Southern Ocean as well. The data would allow comparison of DSW formation between the polar oceans.

\section{Conclusions}

Sea currents in the South and North Atlantic Ocean form two separate hydraulic circulations. The primary driving forces of the surface currents are the thrust from the trade winds and westerlies. Water transported by NEC from the west coast of Central Africa $\left(10^{\circ} \mathrm{N}\right.$ to $20^{\circ} \mathrm{N}, 15^{\circ} \mathrm{W}$ to $\left.17^{\circ} \mathrm{W}\right)$ forms the bulk of the flow in the GSC. Part of the water transported by the SEC is directed northwest as the NBC. Its flow strengthens by $7.5 \mathrm{~Sv}$ the flow of the GSC during boreal winter. Heat from the Southern Hemisphere is then transported deep into the North Atlantic Ocean. The westerlies are an important driving force of the Gulf Stream and the NAC in the North Atlantic Ocean.

In the Arctic and Southern oceans, the seawater freezes in wintertime. One-year-old sea ice can hold only less than $6 \%$ of salt. Due to brine ejection under the ice-cover a salt gradient level is generated which ultimately forces the descent of the surface water by gravity alone. Here it is called descending salty water (DSW). The annual amount of DSW is $21.7 \mathrm{~Sv}$ and in the Southern Ocean $26 \mathrm{~Sv}$. The annual average downward thrust created for the outflowing undercurrents in both oceans is $44,000 \mathrm{~N} / \mathrm{m}^{2}$. This is the suction of the GSC as well.

Due to the bottom topography, the outflow of the DSW in the Arctic Ocean and the inflow of compensating surface water (by the Gulf Stream) are concentrated in confined passages. In the Southern Ocean, the DSW outflows piecemeal and freely in every direction. The compensating surface water is provided by the AnCoC and ACC.

Most of the DSW outflow from the Arctic Ocean occurs via the Labrador Sea towards the coast of northwest Africa as the North Atlantic Undercurrent (NAUC). The direction of the flow is determined by the suction at the starting point of the NEC, which tends to be void of water. The flow and the fluid dynamics of the NAUC as well as the other major cold undercurrents follow Pascal's law and Bernoulli's equation. Upwellings provide an unobstructed passage for a continuous flow of undercurrents. The water molecules moving along streamlines trade speed for height or for pressure. Due to this exchange, the flow of the NAUC slows and the flow bed widens. Subsequently, the NAUC upwells along the 3,500 km of coastal area from A Coruña (NW Spain) to Dakar (NW Africa).

Some of the Arctic DSW from the Norwegian Sea also flows directly south, over the IFSR into the West European Basin and then contributes to the flow of the NAUC and the upwellings along the coasts of Iberia and northern Morocco. The Portugal and Canary currents transport the upwelled waters to the NEC.

DSW formed in the continental shelves of the Arctic and Southern Ocean have to travel long distances in the sea bottom, during which time DSW acquires many nutrients. When the DSW upwells, high nutritional water feeds rich phytoplankton niches. Phytoplankton can be detected by multiple means of detection. Subsequently, upwellings are important indicators of cold undercurrents.

In double diffusive convection (DDC), the driving force is the hundredfold difference in molecular diffusion rates between heat and salt. The phenomenon called salt fingering is typical of DDC. In the abyssal oceans the mixing of water is relatively weak and intermittent, driven by DDC. The temperature difference between the warm and underlying cool water $(\Delta \mathrm{T})$ and salinity differences are low.

When warm water cools in the North Atlantic Ocean under unfrozen sea conditions, the density of the water does not increase to such an extent that it could sink by gravity alone. Due to the turbulence in the first $100 \mathrm{~m}$ and the relatively low $\Delta \mathrm{T}$ between the warm and cool water, DDC does not produce the DSW.

However, DDC is vigorous when the $\Delta \mathrm{T}$ is great. Such occasion includes the confluence of $\mathrm{BraC}$ vs. MalC in which two retroflected eastbound surface currents are formed: the first at $38^{\circ} \mathrm{S}$, being the beginning of the South Atlantic Current (SAC), and the second at $50^{\circ} \mathrm{S}$. In both of these currents the $\mathrm{BraC}$ water has the majority over the MalC water. However, the proportion of the $\mathrm{BraC}$ water, and its southbound momentum, in the $50^{\circ} \mathrm{S}$ current is greater than in the SAC. This difference is causing two latitudinally different retroflections.

Between and/or under the salt fingers, at the level of the MalC deep core, the horizontal movement of the $\mathrm{BraC}$ water is already slowed down so much that it does not influence to the MalC horizontal momentum. Subsequently, this part of the MalC continues to flow in a more or less unchanged direction of momentum through the confluence 
zone. Finally, the Mal $\mathrm{C}$ upwells in the Capo Frio region $\left(23^{\circ} \mathrm{S}\right)$ and in front of the Baía de Todos os Santos $\left(13^{\circ} \mathrm{S}\right)$.

The retroflection of the AguC occurs in front of the Agulhas Bank. The BenC approaches as a wide flow from the southwest. Due to the Agulhas Bank, its flow rises. The $\Delta \mathrm{T}$ between the warm and cool water is great, so DDC is vigorous. A large salt finger, more than $250 \mathrm{~km}$ wide and over 1,200 $\mathrm{m}$ deep, forms. The horizontal movement of the interacting currents in the confluence zone slows due to the vertical movement of the water. The waters are unevenly mixed. The SAC has the ambient water temperature and salinity, and it does not participate in the DDC. However, by its flow, it leaches most of the AguC and BenC stillstand or slowly moving water with it. The deep core of the BenC is more or less untouched by the confluence. The Agulhas Bank divides deep core of BenC into two branches. The western part flows north along the coast of western South Africa (BenC), and the eastern part flows north along the coast of the eastern South Africa $\left(\mathrm{BenC}_{\mathrm{E}}\right)$. This is known as the Agulhas Undercurrent as well.

The AguC/BenC eddies are compensating the heat transported by the NBC via GSC into the North Atlantic Ocean with the heat from the Pacific and Indian Oceans.

The pressure and the absence of important driving forces prevent formation of important sea currents in abyssal waters, except perhaps in the Southern Ocean. Compared to the North Atlantic, the North Pacific Ocean is fresher. This is likely due to the overflow of fresher meltwater/lowest density DSW from the Arctic Ocean to the Pacific Ocean via the Bering Strait. The remaining water is a slightly saltier. Its cycling as the GSC and NAUC has, over time, increased the salinity of North Atlantic Ocean.

\section{List of Abbreviations}

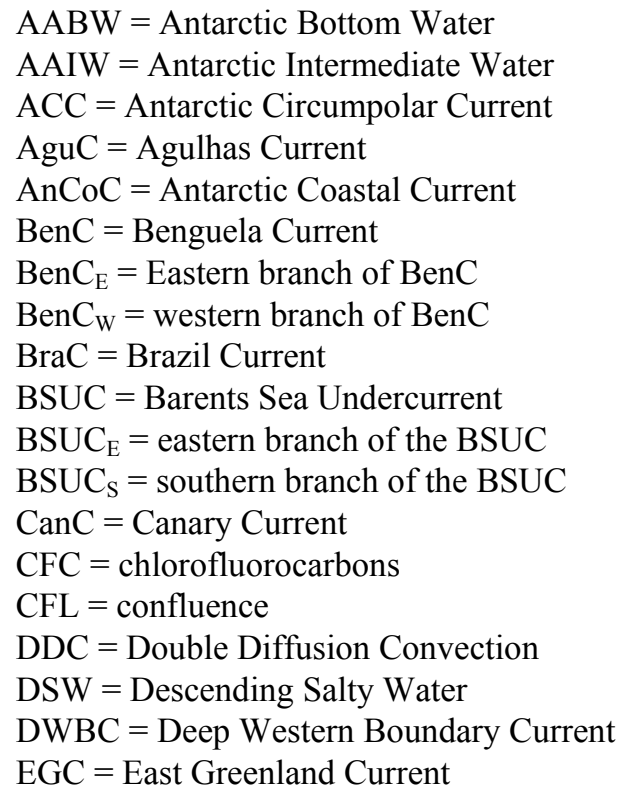

\author{
$\mathrm{sEGC}=$ shelfbreak EGC \\ ESSUC $=$ East Siberian Shelf Undercurrent \\ GBN $=$ Grand Bank of Newfoundland \\ $\mathrm{GSC}=$ Gulf Stream Currents \\ IFSR $=$ Iceland - Faroe-Scotland Ridge \\ IrmC $=$ Irminger Current \\ $\operatorname{IrmC}_{\mathrm{W}}=$ western branch of the IrmC \\ ISOW $=$ Iceland - Scotland Overflow Water \\ $\mathrm{LabC}=$ Labrador Current \\ $\mathrm{LabC}_{\mathrm{S}}=$ southern branch of the $\mathrm{LabC}$ \\ $\mathrm{MalC}=$ Malvinas (Falkland) Current \\ NAC $=$ North Atlantic Current \\ NADW $=$ North Atlantic Deep Water \\ NAUC $=$ North Atlantic Undercurrent \\ $\mathrm{NBC}=$ North Brazil Current \\ $\mathrm{NCaC}=$ North Cape Current \\ $\mathrm{NEC}=$ North Equatorial Current \\ $\mathrm{NECC}=$ North Equatorial Countercurrent \\ NEUC $=$ North Equatorial Undercurrent \\ $\mathrm{NIJ}=$ North Icelandic Jet \\ NW $=$ Northwest \\ $\mathrm{NwAC}=$ Norwegian Atlantic Current \\ $\mathrm{PF}=$ Polar Front \\ $\mathrm{PUC}=$ Polar Undercurrent \\ $\mathrm{RR}=$ Reykjanes Ridge \\ $\mathrm{SAC}=$ South Atlantic Current \\ $\mathrm{SAF}=$ Subantarctic Front \\ $\mathrm{SE}=$ Southeast \\ $\mathrm{SEC}=$ South Equatorial Current \\ sSEC $=$ southern branch of the SEC \\ $\mathrm{nSEC}=$ northern branch of the SEC \\ SIOC $=$ South Indian Ocean Current \\ WGC $=$ West Greenland Current \\ WSC $=$ West Spitsbergen Current \\ WTR $=$ Wyville Thomson Ridge
}

\section{Acknowledgements}

I am very grateful to Matthew Wuethrich from the University of Jyväskylä Language Services for revising the English of the manuscript. I thank my daughter Heidi for drawing Figures 1, 5, the sea currents in Figures 7, 8, 10 , and 14, and my wife Ritva for her support.

\section{REFERENCES}

[1] G. L. Pickard and W. J. Emery, Descriptive Physical Oceanography. An Introduction, Butterworth-Heinemann, Oxford, 2002. ISBN: 0-7506-2-2759-X. 5. enlarged edition (with SI units), pp 168-169.

[2] https://en.wikipedia.org/wiki/Thermohaline circulation.

[3] https://en.wikipedia.org/wiki/Brazil\%E2\%80\%93Malvinas _Confluence. 
[4] B. A. Warren, Why is no deep water formed in the North Pacific? Journal of Marine Research, 41, 327-347, 1983.

[5] https://earthobservatory.nasa.gov/images/77461/bering-seateeming-with-ice.

[6] M. Dengler, F. A. Schott, C. Eden, P. Brandt, J. Fischer and J. Zantropp, Break-up of the Atlantic deep western boundary current into eddies at 8 degrees S, Nature, Vol. 432, No. 7020, 1018-1020, 2004. DOI: 10.1038/nature03 134.

[7] W. M. Smethie Jr., R. A. Fine, A. Putzka and E. P. Jones Tracing the flow of North Atlantic Deep Water using chlorofluorocarbons, Journal of Geophysical Research, Vol. 105, No. C6, 14,297-14,323, 2000.

[8] R. L. Molinari, R. A. Fine and E. Johns, The Deep Western Boundary Current in the tropical North Atlantic Ocean, Deep Sea Research Part I. Oceanographic Research Papers, Vol. 39, No. 11-12, 1967-1984, 1992. https://doi.org/10.1 016/0198-0149(92)90008-H.

[9] M. Rhein, M. Walter, C. Mertens, R. Steinfeldt and D. Kieke, The circulation of North Atlantic Deep Water at $16^{\circ} \mathrm{N}$, 2000-2003, Geophysical Research Letters, Oceans, Vol. 31, No. 14, 2004. https://doi.org/10.1029/2004GL019993.

[10] https://pubchem.ncbi.nlm.nih.gov/compound/Dichlorodiflu oromethane\#section=Density.

[11] https://pubchem.ncbi.nlm.nih.gov/compound/Trichlorofluor omethane\#section=Density.

[12] W. Roether, B. Klein and K. Bulsiewicz, Apparent loss of CFC - 113 in the upper ocean, Journal of Geophysical Research Oceans, Vol. 106, No. C2, 2679 - 2688, 2001. https://doi.org/10.1029/1999JC000079.

[13] A. Gargett and G. Holloway, Differential vertical transport of heat and salt by weak stratified turbulence, Geophysical Research Letters Vol. 25, No. 15, 2773-2776, 1998.

[14] R. W. Schmitt, Double diffusion in oceanography, Annual Review of Fluid Mechanics, 26, 255-285, 1994.

[15] https://www.convertunits.com/from/technical+atmosphere/t $\mathrm{o} / \mathrm{n} / \mathrm{m} 2$.

[16] R. K. Mobley, Fluid Power Dynamics, Part I, Chapter 2, Forces in Liquids, 2000 https://doi.org/10.1016/B978-075067174-3/50053-6.

[17] H. C. Ohanian, Physics, 2nd Edition, Expanded, N. W. Norton \& Co, New York. ISBN 0-393-95750-0, 1989.

[18] http://www.csgnetwork.com/water_density_calculator.html.

[19] https://www.britannica.com/science/seawater/Density-of-se awater-and-pressure.

[20] L. D. Talley, Salinity Patterns in the Ocean, Vol. 1, The Earth system: Physical and chemical dimensions of global environmental change, pp 629-640. Ed. by M. C. MacCracken and J. S Perry in Encyclopedia of Global Environmental Change John Wiley \& Sons, Ltd, Chichester, 2002. ISBN 0-471-97796-9.

[21] https://serc.carleton.edu/NAGTWorkshops/earlyearth/questi ons/formation_oceans.html.

[22] https://www.britannica.com/science/westerlies.
[23] M. W. Schmidt and J. E. Hertzberg, Abrupt Climate Change During the Last Ice Age. Nature Education Knowledge Vol. 3, No.10, 11, 2011.https://www.nature.com/scitable/knowl edge/library/abrupt-climate-change-during-the-last-ice-242 88097.

[24] K. Jochumsen, S. M. Schnurr and D. Quadfasel, Bottom temperature and salinity distribution and its variability around Iceland, Deep-Sea Research Part I: Oceanographic Research Papers, Vol. 111, 79-90, 2016.https://doi.org/10. 1016/j.dsr.2016.02.009.

[25] Legeckis, R. and A. Gordon, Satellite observations of the Brazil and Falkland Currents - 1975 to 1976 and 1978 Deep-Sea Research, Vol. 29, No. 3A, 375-401, 1982.

[26] https://earthobservatory.nasa.gov/images/5479/malvinas-cu rrent-south-america.

[27] A. L. Gordon, Brazil-Malvinas Confluence-1984, Deep Sea Research Part A. Oceanographic Research Papers, Vol. 36, No. 3, 359 - 361, 363 - 384, 1989. https://doi.org/10.1016/ 0198-0149(89)90042-3].

[28] S. L. Garzioli and Z. Garrafo, Transports, frontal motions and eddies at the Brazil-Malvinas Currents, Deep-Sea Research, Vol. 36, No. 5, 681-703, 1989.

[29] R. P. Matano, E. D. Palma and A. R. Piola, The influence of the Brazil and Malvinas Currents on the Southwestern Atlantic Shelf circulation, Ocean Science, Vol. 6, 983-995, $2010 \quad$ www.ocean-sci.net/6/983/2010/ doi:10.5194/os-6-983-2010.

[30] L. D. Talley, G. L. Pickard, W. J. Emery and J. H. Swift (Eds.) Descriptive Physical Oceanography - An Introduction, Chapter 14.5, Eddy Variability and Diffusivity, Elsevier/AP 6th edition 2011. ISBN 978-0-7506-4552-2.

[31] C. S. Meinen, S. L. Garzoli, R. C. Perez, E. Campos, A. R. Piola, M. P. Chidichimo, S. Dong and O. T. Sato, Characteristics and causes of Deep Western Boundary Current transport variability at $34.5^{\circ} \mathrm{S}$ during 2009-2014, Ocean Science, Vol. 13, 175-194, 2017 www.ocean-sci.net/13/175/2017/ doi:10.5194/os-13-175-2017.

[32] https://www.britannica.com/science/Atlantic-South-Equator ial-Current.

[33] D. M. Fratantoni and D. A. Glickson, North Brazil Current Ring Generation and Evolution Observed with SeaWiFS, Journal of Physical Oceanography, Vol. 32, No. 3, 10581074, 2002. https://doi.org/10.1175/1520- 0485(2002)032< 1058:NBCRGA>2.0.CO;2.

[34] R. G. Soutelino, I. C. A. da Silva, A. Gangopadhyay and J. A. Miranda, Is the Brazil Current eddy - dominated to the north of $20^{\circ} \mathrm{S}$ ? Geophysical Research Letters, Vol. 38, No. 3, 2011. https://doi.org/10.1029/2010GL046276.

[35] R. R. Rodrigues, L. M. Rothstein, and M. Wimbush, Seasonal variability of the South Equatorial Current bifurcation in the Atlantic Ocean: A numerical study, Journal of Physical Oceanography, Vol. 37, No. 1, 16-30, 2007, DOI:10.1175/JPO2983.1.

[36] https://www.britannica.com/science/equatorial-countercurre nt\#ref65598. 
[37] M. C. Wattimena, A. S. Atmadipoera, M. Purba, I. W. Nurjaya and F. Syamsudin, Indonesian Throughflow (ITF) variability in Halmahera Sea and its coherency with New Guinea Coastal Current, IOP Conf. Series: Earth and Environmental Science 176 (1), $012011 ， 2018$. DOI: 10.1088/1755-1315/176/1/012011.

[38] P. L. Richardson and T. K. McKnee Average Seasonal Variation of the Atlantic Equatorial Currents from Historical Ship Drifts, Journal of Oceanography, Vol 14, 1226-1238, 1984.

[39] P. L. Richardson and G. Reverdin, Seasonal Cycle of Velocity in the Atlantic North Equatorial Countercurrent as Measured by Surface Drifters, Current Meters, and Ship Drifts, Journal of Geophysical Research, Vol. 92, No. C4, 3691-3708, 1987.

[40] https://oceancurrents.rsmas.miami.edu/atlantic/guinea.html.

[41] S. G. H. Philander, Upwelling in the Gulf of Guinea. Journal of Marine Research, Vol. 37, 23-33, 1979.

[42] S. G. Philander, Atlantic Ocean equatorial currents, Princeton University, pp. 189-190, 2001. Princeton, NJ, USA Academic Press doi:10.1006/rwos.2001.0361.

[43] W. H. Berger and G. Wefer, Central Themes of South Atlantic Circulation, In G. Wefer, W. H. Berger, G. Siedler and D. J. Web (Eds.), The South Atlantic: Present and Past Circulation, Springer Verlag, Berlin, 1996. ISBN: 978-3-642-80355-09.

[44] Z. D. Garraffo, W. E. Johns, E. P. Chassaginet and G. J. Goni, North Brazil Current rings and transport of southern waters in a high resolution numerical simulation of the North Atlantic, Elsevier Oceanography Series, Vol. 68, 375-409, 2003. https://doi.org/10.1016/S0422-9894(03)80155-1.

[45] W. D. Wilson and W. E. Johns, Velocity structure and transport in the Windward Islands Passages, Deep Sea Research Part I: Oceanographic Research Papers, Vol. 44, No. 3, 487-450, 1997. https://doi.org/10.1016/S0967-0637(96)00113-6.

[46] F. A Schott, T. N. Lee and R. Zantopp, Variability of Structure and Transport of the Florida Current in the Period Range of Days to Seasonal, Journal of Physical Oceanography, Vol. 18, No. 9, 1209-1230, 1988. DOI: 10.1175/1520-0485(1988)018<1209:VOSATO >2.0.CO;2

[47] C. S. Meinen, W. E. Jones, B. I. Moat, R. H. Smith, E. M. Johns, D. Rayner, E. Fraika-Williams, R. F. Garcia, S. L. Garzoli, Structure and Variability of the Antilles Current at 26.5 ${ }^{\circ}$, JGR Oceans, Vol. 124, No. 6, 3700-3723, 2019. https://doi.org/10.1029/2018JC014836.

[48] K. Leaman, E, Johns, T. Rossby, The average distribution of volume transport and Potential Vorticity with temperature at three sections across the Gulf Stream, Journal of Physical Oceanography, Vol. 19, No 1, 36-51, 1989. doi: 10.1175/1 520-0485(1989)019<0036:TADOVT>2.0.CO;2.

[49] W. D. Richard, E. D. Alexander, V. Soloviev, A. Hirons, C. Maingot, C. W. Dean, R. E. Dodge, A. E. Yankovsky, J. Wood, R. H. Weisberg, M. E. Luther and J. P. McCreary, Southward flow on the western flank of the Florida Current, Deep Sea Research Part I. Oceanographic Research Papers, Vol. 125, 94-105, 2017.https://doi.org/10.1016/j.dsr.2017. 05.002 .
[50] P. L. Richardson, Eddy kinetic energy in the North Atlantic from surface drifters. Journal of Geophysical Research 88, 4355-4367, 1983.

[51] M. Burrows, S. A. Thorpe, Drifter observations of the Hebrides slope current and nearby circulation patterns, Annales Geophysicae, Vol 17, 280-302, 1999.

[52] L. Houpert, M. Inall, E. Dumont, Stefan Francois Gary, C. Johnson, Marie Porter, W. E. Johns and Stuart Cunningham, Structure and Transport of the North Atlantic Current in the Eastern Subpolar Gyre from Sustained Glider Observations, Journal of Geophysical Research: Oceans, Vol. 123, No. 8, 6019-6038, 2018. DOI: 10.1029/2018JC014162.

[53] M. Inall, P. Gillibrand, C. Griffiths, N. MacDougal and K. Blackwell, On the oceanographic variability of the North-West European Shelf to the West of Scotland, Journal of Marine Systems Vol. 77, 210-226, 2009.

[54] A. Sarafanov, A. Falina, H. Mercier, A. Sokov, P. Lherminier, C. Gourcuff, S. Gladyshev, F. Gaillard and N. Daniault, Mean full-depth summer circulation and transports at the northern periphery of the Atlantic Ocean in the 2000s, Journal of Geophysical Research, Vol. 117, C01014, 2012. DOI:10.1029/2011JC007572.

[55] R. S. Pickart, M. A. Spall, D. J. Torres, K. Våge, H Valdimarsson, C. Nobre, G. W. K. Moore, S. Jonsson and D. Mastropole, The North Icelandic Jet and its relationship to the North Icelandic Irminger Current, Journal of Marine Research, Vol. 75, 605-639, 2017.

[56] J. A. Brearley, R. S. Pickart, H. Valdimarsson, S. Jonsson, R. W. Schmitt, T. W. N. Haine, The East Greenland boundary current system south of Denmark Strait, Deep Sea Research Part I: Oceanographic Research Papers, Vol 63, 1-19, 2012, doi:10.1016/j.dsr.2012.01.001.

[57] S. Ribeiro, M. Moros, M. Ellegaard and A. Kuijpers, Climate variability in West Greenland during the past 1500 years: evidence from a high-resolution marine palynological record from Disko Bay, Boreas, Vol. 41, pp. 68-83, 2011, 10.1111/j.1502-3885.2011.00216.x. ISSN 0300-9.

[58] K. A. Orvik, Ø. Skagseth, and M. Mork, Atlantic inflow to the Nordic Seas: Current structure and volume fluxes from moored current meters, VM-ADCP and SeaSoar-CTD observations 1995-1999, Deep Sea Research, Part I, Vol. 48, 937-957, 2001.

[59] https://encyclopedia2.thefreedictionary.com/Norwegian $+\mathrm{Cu}$ rrent.

[60] R. H. Bourke and A. M. Weigel, The Baroclinic Circulation of the West Spitsbergen Current, pp 47-67, 1989, In S. J. Neshyba, Ch. N. K. Mooers, R. L. Smith and R. T. Barber (Eds.) Poleward Flows Along Eastern Ocean Boundaries, Springer Verlag.

[61] M. A. Janout, J. Hölemann, L. Timokhov, O. Gutjahr, and G. Heinemann, Circulation in the northwest Laptev Sea in the eastern Arctic Ocean: Crossroads between Siberian River water, Atlantic water and polynya-formed dense water, Journal of Geophysical Research. Oceans, Vol. 122, 2017. DOI:10.1002/2017JC013159.

[62] C. Peralta-Ferriz, and R. A. Woodgate, The dominant role of the East Siberian Sea in driving the oceanic flow through 
the Bering Strait - Conclusions from GRACE ocean mass satellite data and in situ mooring observations between 2002 and 2016, Geophysical Research Letters, 44, 11,472-11,481, 2017. doi:10.1002/2017GL075179.

[63] Freezing Point Calculator https://www.mt-oceanography.inf o/Utilities/freeze.html.

[64] https://www.britannica.com/science/bottom-water.

[65] G. V. Alekseev, O. M. Johannessen, A. A. Korablev, V. V. Ivanov and D. V. Kovalevsky, Interannual variability in water masses in the Greenland Sea and adjacent areas, Polar Research Vol 20, No. 2, 201-208, 2001.

[66] A. J. Gow and W. B. Tucker III, Physical and Dynamic Properties of Sea Ice in the Polar Oceans, U.S. Army Corps of Engineers Cold Regions Research \& Engineering Laboratory, p. 3, 1991. https://pdfs.semanticscholar.org/70 d4/ae2567ad692155fbda4dc3bae377a10f5ce0.pdf.

[67] G. F. N. Cox and W.F. Weeks, Salinity variations in sea ice, Journal of Glaciology, Vol. 13, No. 67,109-120, 1974.

[68] https://nsidc.org/cryosphere/seaice/characteristics/brine_sali nity.html.

[69] B. Rudels, Arctic Ocean Circulation, Encyclopedia of Ocean Science (Second Edition), 211-225, 2009. https://doi.org/1 0.1016/B978-012374473-9.00601-9.

[70] NSIDC, National Snow \& Ice Data Center, Arctic vs. Antarctic https://nsidc.org/cryosphere/seaice/characteristic s/difference.html.

[71] NSIDC, National Snow \& Ice Data Centre, Arctic Sea News \& Analysis, Sea Ice Data and Analysis Tools, Arctic Interactive Sea Ice Graph, https://nsidc.org/arcticseaicenew s/sea-ice-tools/.

[72] AOOS, Alaska Ocean Observing System. https://aoos.org/i ce-detection-buoy/.

[73] S. Falk-Petersen, V. Pavlov, J. Berge, F. Cottier, K. M. Kovacs and C. Lydersen, At the rainbow's end: high productivity fueled by winter upwelling along an Arctic shelf, Polar Biology, Vol. 38, No. 1, 5-11, 2015. DOI 10.1007/s00300-014-1482-1.

[74] http://bcre.org.za/seaatlas/index.php?p=winddrivencoastalu pwelling.php.

[75] F. Nilsen, R. Skogseth, J. Vaardal-Lunde and M. Inall, A Simple Shelf Circulation Model: Intrusion of Atlantic Water on the West Spitsbergen Shelf, Journal of Physical Oceanography Vol. 46, No. 4, 1209-1230, 2016. DOI: 10.1175/JPO-D-15-0058.1.

[76] https://en.wikipedia.org/wiki/Siberian_Shelf.

[77] J. Peña-Izquierdo, J. L. Pelegrí, M. V. Pastor, P. Castellanos, M. Emelianov, M. Gasser, J. Salvador and E. Vázquez-Domínguez, The continental slope current system between Cape Verde and the Canary Islands Scientia Marina 76S1, 65-78, 2012, Advances in Spanish Physical Oceanography M. Espino, J. Font, J.L. Pelegrí, A. Sánchez-Arcilla (Eds.). DOI: 10.3989/scimar.03607.18C. ISSN 0214-8358.

[78] A. Münchow and H. Melling, Ocean current observations from Nares Strait to the west of Greenland: Interannual to tidal variability and forcing, Journal of Marine Research, Vol. 66, 801-833, 2008.

[79] S. Jonsson and H. Valdmarsson 2004, A new path for the Denmark Strait overflow water from the Iceland Sea to Denmark Strait, Geophysical Research Letters, Vol. 31, No. 21, 2004. https://doi.org/10.1029/2003GL019214.

[80] D. Mastropole, R. S. Pickart, H. Valdimarsson, K. Våge, K. Jochumsen, and J. Girton, On the hydrography of Denmark Strait, Journal of Geophysical Research. Oceans, Vol. 122, 306-321, 2017. DOI:10.1002/2016JC012007.

[81] M. Leppäranta, Freezing of Lakes and the Evolution of their Ice Cover, 2015, Springer, Heidelberg. ISBN: 978-3-643-29080-0.

[82] L. Håvik, K. Våge, R. S. Pickart, B. Harden, W.-J. Von Appen, S. Jónsson, and S. Østerhus, Structure and Variability of the Shelfbreak East Greenland Current North of Denmark Strait, Journal of Physical Oceanography, Vol. 47, No. 10, 2631-2646, 2017. DOI: 10.1175/JPO-D-17-0062.1.

[83] L. Midttun, Climatic fluctuations in the Barents Sea. Rapp. P.-v. Réun. Cons. int. Explor. Mer, 188: 23-35, 1989.

[84] W. H. Peterson and C. G. H. Rooth Formation and exchange of deep water in the Greenland and Norwegian Seas. Deep-Sea Research, Vol. 23, 273-283, 1976.

[85] N. L. Beaird, P. B. Rhines, and C. C. Eriksen, Overflow Waters at the Iceland-Faroe Ridge Observed in Multiyear Seaglider Surveys, Journal of Physical Oceanography, Vol. 43, No. 11, 2334-2351, 2013 https://doi.org/10.1175/JPO-D-13-029.1.

[86] C. Johnson, T. Sherwin, D. Smythe-Wright, T. Shimmield and W. Turrell, Wyville Thomson Ridge Overflow Water: Spatial and temporal distribution in the Rockall Trough, Deep Sea Research Part I: Oceanographic Research Papers, Vol. 57, No. 10, 1153-1162, 2010. https://doi.org/10.1016/ j.dsr.2010.07.006.

[87] S. Zou, S. Lozier, W. Zenk, A. Bower, and W. Johns, Observed and modeled pathways of the Iceland Scotland Overflow Water in the eastern North Atlantic, Progress in Oceanography, Vol. 159, 211-222, 2017.https://doi.org/10 .1016/j.pocean.2017.10.003.

[88] S. Zou, Observed southward spreading of the Iceland Scotland Overflow Water along the eastern flank of the Mid-Atlantic Ridge, 2017. OSNAP Overturning in the Subpolar North Atlantic Program, https://www.o-snap.org/observed-southward-spreading-ofthe-iceland-scotland-overflow-water-along-the-eastern-flan k-of-the-mid-atlantic-ridge/.

[89] F. A. McLaughlin, E. C., Carmack, R. G. Ingram, W. J., Williams and C. Michel, Oceanography of the Northwest Passage. The Sea, Vol. 14, 1211-1242, 2004. Ed. by A. R. Robinson and K. H. Brink. Harvard University Press. ISBN 0-674-C2004. https://www.researchgate.net/publication/2 30801780_Oceanography_of the_Northwest_Passage.

[90] John (Qiang) Wang, Paul G. Myers, Xianmin Hu, Andrew B.G. Bush, Numerical modeling of the circulation and sea ice in the Canadian Arctic, 2004.

[91] J. R. N..Lazier and D.G. Wright, Annual Velocity variations 
in the Labrador Current, Journal of Physical Oceanography, Vol. 23, 659-678, 1993.

[92] F. Straneo and F. Saucier, The outflow from Hudson Strait and its contribution to the Labrador Current, Deep Sea Research Part I Oceanographic Research Papers, Vol. 55, No. 8, 2008. DOI: 10.1016/j.dsr.2008.03.012.

[93] P. L. Richardson, Florida current, Gulf Stream, and Labrador Current, 1st Edition of Encyclopedia of Ocean Sciences, Vol. 2, pp 1054-1064, 2001, Elsevier Ltd.

[94] https://visibleearth.nasa.gov/images/68117/phytoplankton-b loom-off-newfoundland)

[95] B. Petrie and C. Anderson, Circulation on the Newfoundland continental shelf, Atmosphere-Ocean, Vol. 21, No. 2, $207-$ 226, 1983. DOI: $10.1080 / 07055900.1983 .9649165$

[96] P. G. Myers, N. Kulan, and M. H. Ribergaard, Irminger Water variability in the West Greenland Current, Geophysical Research Letters, Vol. 34, L17601, 2007 DOI:10.1029/2007GL030419.

[97] R. E. Kangas and G. L. Hufford, An upwelling rate for Massachusetts Bay, Journal of Geophysical Research. Vol. 79, No. 15, 2231-2236, 1974.https://doi.org/10.1029/JC07 $9 \mathrm{i} 015 \mathrm{p} 02231$.

[98] B. Richaud, Y.-O. Kwon, T. M. Joyce, P. S. Fratantoni and S. J. Lentz, Surface and bottom temperature and salinity climatology along the continental shelf off the Canadian and U.S. East Coasts, Continental Shelf Research, Vol. 124, No.

1, 165 - 181, 2016. https://doi.org/10.1016/j.csr.2016.06.0 05 .

[99] A. Bode, M. Àlvarez, M. Ruiz-Villareal and M. M. Varela, Changes in phytoplankton production and upwelling intensity off A Coruña (NW Spain) for the last 28 years, Ocean Dynamics, Vol. 69, No. 7, 861-873, 2019. DOI: 10.1007/s10236-019-01278-y.

[100] J. Arístegui, E. D. Barton, X. A. Álvarez-Salgado, A. M.P. Santos, F. G. Figueiras, S.Kifani, S. Hernández-León, E. Mason, E. Machú and H. Demarcq, Sub-regional ecosystem variability in the Canary Current upwelling, Progress in Oceanography, Vol. 83, 33-48, 2009. DOI: 10.1016/j.poce an.2009.07.031.

[101] R. H Parrish, C. S. Nelson, and A. Bakun, Transport mechanisms and reproductive success of fishes in the California Current, Biological Oceanography, Vol. 1, 175203, 1981

[102] A. Bakun, and C. S. Nelson, The seasonal cycle of wind stress curl in subtropical eastern boundary current regions, Journal of Physical Oceanography, Vol. 21, 1815-1834, 1991.

[103] M. Gómez-Letona, A. G. Ramos, J. Coca and J. Arístegui, Trends in Primary Production in the Canary Current Upwelling System-A Regional Perspective Comparing Remote Sensing Models. Front. Mar. Sci. Vol 4, 370, 2017. DOI: $10.3389 /$ fmars.2017.00370.

[104] W. S Wooster A. Bakun, and D. R. McLain, The seasonal upwelling cycle along the eastern boundary of the North Atlantic, Journal of Marine Research, Vol. 34, 131-140, 1976.
[105] Tomczak, M., and J. S. Godfrey, Regional Oceanography: An Introduction, 422 pp., Pergamon, New York, 1994.

[106] F. Criado-Aldeanueva, J. Garcia-Lafuente, J. M. Vargas, J. Del Rio, A. Vazquez, A. Reul and A. Sanchez Distribution and circulation of water masses in the Gulf of Cadiz from in situ observations. Deep-Sea Research II Vol. 53, 1144 1160, 2006. DOI: 10.1016/j.dsr2.2006.04.012.

[107][E. Navarro-Pérez and E.D. Barton, Seasonal and interannual variability of the Canary Current. Scientia Marina, 65, 205-213, 2001

[108] A. L.Gordon and C.L. Greengrove, Geostrophic circulation of the Brazil-Falkland confluence. Deep-Sea Research, Vol. 33, 573-585, 1986.

[109] F. M. Santos, G. C. Lessa, M. Cirano, R. M. Domingues and C. A. D. Lentini, Localized coastal upwelling at the Brazil Current formation zone $\left(13^{\circ} \mathrm{S}\right)$, Anais XVII Simpósio Brasileiro de Sensoriamento Remoto - SBSR, João Pessoa-PB, Brasil, 25 a 29 de abril de 2015, INPE.

[110] S. A. Coelho-Souza, M. S. López, J. R. D. Guimarães, R. Coutinho and R. N. Candella, Biophysical interactions in the Cabo Frio upwelling system, southeastern Brazil, Brazilian Journal of Oceanography, Vol. 60, No. 3, 2012. http://dx.doi.org/10.1590/S1679-87592012000300008.

[111] L. Stramma and R.G. Peterson, The south Atlantic current, Journal of Physical Oceanography, Vol. 20, 846-859, 1990.

[112] R. G. Peterson and L. Stramma, Upper-level circulation in the South Atlantic Ocean, Progress in. Oceanography, Vol. 26, 1-73, 1991.

[113] W. P. M. de Ruijter, A. Biastoch, S. S. Drijfhout, J. R. E. Lutjeharms, R. P. Matano, T. Pichevin, P. J. van Leeuwen and W. Weijer, Indian-Atlantic interocean exchange Dynamics, estimation and impact, Journal of Geophysical Research, Vol. 104, No. C9, 20,885-20,910, 1999.

[114] A. S. I. Nkwinkwa N., M. Rouault and J. A. Johannessen, Latent Heat Flux in the Agulhas Current, Remote Sensing, Vol. 11, No. 13, 1576-609, 2019. https://doi.org/10.3390/r s11131576.

[115] A. L. Gordon, J. R. E. Lujeharms, M. L. Grundlingh and L. Doherty, Stratification and circulation at the Agulhas Retroflection, Deep Sea Research Part A. Oceanographic Research Papers, Vol. 34, No. 4, 565-599, 1987. https://doi.org/10.1016/0198-0149(87)90006-9.

[116] https://www.britannica.com/place/Benguela-Current.

[117] R. P. Matano, C. G. Simionato, W. P. de Ruijter, P. J. van Leeuween, P. T. Strub, D. B. Chelton and M. G. Schiax, Seasonal variability in the Agulhas Retroflection region, Geophysical Research Letters, Vol. 25, No. 23, 4361-4364, 1998. DOI: 10.1029/1998GL900163.

[118] L. M. Beal and H. L. Bryden, Observations of an Agulhas Undercurrent, Deep-Sea Research, Vol. 44, No. 9-10, 1715-1724, 1997.

[119] Nasa, March 28, 1999, https://earthobservatory.nasa.gov/i mages/447/agulhas-current-south-africa

[120] Nasa, November 18, 2018, https://www.earth.com/image/p hytoplankton-bloom-off-the-coast-of-south-africa/ 
[121] F. A. Shillington, C. J. C. Reason, C. M. Duncombe Rae, P. Florenchie, and P. Penven Large Scale Physical Variability of the Benguela Current Large Marine Ecosystem (BCLME), Large Marine Ecosystems, Vol. 14, 49-70, 2006.

[122] S. Majumder and C. Schmid,A study of the variability in the Benguela Current volume transport Ocean Science, Vol. 14, 273-283, 2018 https://doi.org/10.5194/os-14-273-2018.

[123] https://oceancurrents.rsmas.miami.edu/atlantic/benguela.ht $\mathrm{ml}$.

[124] R. Barlow, H. Sessions, M. Balarin, S. J. Weeks, C. P. Whittle and L. Hutchings, Seasonal variation in phytoplankton in the southern Benguela: Pigment indices and ocean colour, African Journal of Marine Science, Vol. 27, No. 1, 2005. DOI: 10.2989/18142320509504086.

[125] K. A. Al-Hashmi, M. R. Claereboudt, A. R. Al-Azri and S. A. Piontovski, Seasonal Changes of Chlorophyll a and Environmental Characteristics in the Sea of Oman, The Open Oceanography Journal, Vol. 4, 107-114, 2010.

[126] D. Giglio and G. C. Johnson, Subantarctic and Polar Fronts of the Antarctic Circumpolar Current and Southern Ocean Heat and Freshwater Content Variability: A View from Argo, Journal of Physical Oceanography, Vol. 46, No. 3, 2016, 749-768. https://doi.org/10.1175/JPO-D-15-0131.1.

[127] A. H. Orsi, T. Whitworth and W. D. Nowlin, On the meridional extent and fronts of the Antarctic Circumpolar Current. Deep-Sea Research Papers Part I: Oceanographic Research Papers, Vol. 42, No. 5, 641 - 673, 1995. DOI: https://doi.org/10.1016/0967-0637(95)00021-W.

[128] https://en.wikipedia.org/wiki/Antarctic_Intermediate_Wate r.

[129] http://glossary.ametsoc.org/wiki/Subantarctic_front.

[130] S. Cunningham, S. G. Alderson, B. A. King and M. a. Brandon, Transport and variability of the Antarctic Circumpolar Current in Drake Passage, Journal of Geophysical Research, Vol. 108, No. C5, 8084, 2003. DOI: 10.1029/2001JC001147.

[131] https://oceancurrents.rsmas.miami.edu/southern/antarctic-c oastal.html.

[132] W. Yao, J. Shi, and X. Zhao Freshening of Antarctic Intermediate Water in the South Atlantic Ocean in 20052014, Ocean Science, Vol. 13, 521-530, 2017 https://doi.o $\mathrm{rg} / 10.5194 / \mathrm{os}-13-521-2017$.

[133] OpenLearn, The oceans Chapter 3.5 The water properties along the Atlantic Ocean. https://www.open.edu/openlearn /ocw $/ \mathrm{mod} /$ oucontent $/ \mathrm{view} . \mathrm{php}$ ?id=20129\&extra=thumbnai lfigure_idm20605008.

[134]B. Qiu, Kuroshio and Oyashio currents, In J. Steele, S. Thorpe and K. Turekian (Eds.), Encyclopedia of Ocean Sciences, 1413 - 1425, 2001 Academic Press.doi:10.1006/ rwos.2001.0350. ISBN 9780122274305. 